\title{
A NATUREZA JURÍDICA DO CASAMENTO ROMANO NO DIREITO CLÁSSICO
}

\author{
José Carlos Moreira Alves \\ Professor Titular do Departamento de Direito Civil \\ da Faculdade de Direito da Universidade de São Paulo
}

\begin{abstract}
Resumo:
Neste artigo, sustenta-se que, à concepção de que o casamento romano clássico era um fato cuja persistência dependia do consentimento contínuo do cônjuge, se opõem objeções, tiradas de textos jurídicos e extrajurídicos do período clássico, que são, até logicamente, intransponíveis.
\end{abstract}

\begin{abstract}
:
This article sustains that, in legal and extralegal texts from the classical Roman period, there are grounds to oppose radically, even from a logical point of view, the concepts that persistence of classical Roman marriage depended upon the continuous agreement of the partner.
\end{abstract}

1. Problema multissecular é o da natureza jurídica do casamento em Roma.

Os próprios juristas romanos não deram maior atenção ao matrimônio como instituto jurídico, tanto assim que deles, a esse respeito, só conhecemos duas obras que não chegaram até nós: De Nuptiis, de Nerácio Prisco, e Liber Singularis de Ritu Nuptiarum, de Modestino.

Desde a Idade Média, porém, os jurisconsultos se têm ocupado com essa questão, examinando-a à luz dos textos romanos jurídicos e literários que sobreviveram.

Os glosadores, de início, caracterizaram-no como contractus personarum (contrato sem conteúdo patrimonial ), e, mais tarde ao que parece, passaram, por influência dos canonistas, a tê-lo como um dos actus legitimi, à semelhança do que ocorria com a adoção. Já os pós-glosadores permaneceram fiéis à tese do contractus personarum, deles não discrepando a Escola que se lhes seguiu a dos Cultos - que o classificou como species societatis ( uma espécie do contrato de sociedade ), o que, aliás, se sustentava na Summa Codicis Tricensis, obra de data incerta, mas não posterior à segunda metade do século XII. Nos séculos XVII e 
XVIII, dominou, amplamente, o entendimento de que o casamento, no Direito Romano, era um contrato, e contrato de sociedade.'

Essas teses, porém, encontraram opositores. No século XVI, Donelo ${ }^{2}-$ ardoroso defensor do casamento romano como species societatis - já sentia necessidade de refutar objeções que, então, se faziam a essa caracterização. Mais tarde, Húbero ${ }^{3}$ era categórico na afirmação de que os antigos não colocaram o casamento entre os contratos, nem ele o era. Mas o ataque mais vigoroso partiu de Glueck, ${ }^{4}$ no século XIX, e talvez houvesse conseguido destruir a doutrina contratualista não fora, principalmente, a atuação de Savigny, que formulou um conceito mais amplo de contrato "contrato é o concurso de muitas pessoas numa concorde declaração de vontade, pela qual vêm determinadas suas relações jurídicas" $"$-, capaz de abranger os acordos de vontade de que resultam quaisquer relações jurídicas, inclusive o matrimônio. Nessa esteira seguiram os pandectistas alemães posteriores a Savigny. Entre os franceses, Ortolan, ${ }^{6}$ sustentando (como séculos antes o fizera Vacário) que a deductio uxoris in domum mariti era elemento essencial à constituição do casamento romano, enquadrou-o entre os contratos reais.

Até o final do século XIX, os autores que criticavam a teoria contratualista se adstringiam a negá-la, sem apresentar outra que a substituísse.

Em 1889, Manenti, no livro Della inopponibilità delle condizioni ai negozi giuridici ed in ispecie delle condizioni apposte al matimonio, ${ }^{7}$ ao tratar do casamento no direito justinianeu, salientou que, para a conclusão do matrimônio nesse período, não se exigia qualquer solenidade, nem a conjunção carnal, sendo suficiente, apenas, o consensus, cuja natureza assim caracterizou:

1. Vide, a propósito, Orestano, La Struttura Giuridica del Matrimonio Romano dal Diritto Classico al Diritto Giustinianeo, vol. I, p. 22 e ss.

2. Comm. de iure ciuili lib. XIII, caps. 18 e 21, in Hugonis Donelli Opera Omnia, III, colunas 955 e ss., ad signum clius, Florentiae, 1841.

3. Praelectionum Iuris Ciuilis Tomi Tres secundum Institutiones et Digesta Iustiniani, tomo I, lib. I, tit. X, n. 2, p. 44, Maceratae, apud Viarcahi et Grazzini Editores, 1838.

4. Commentario alle Pandette, liv. XXIII, trad. D'Ancora, p. 143 e 144, Società Editrice Libraria, Milano, 1898.

5. Sistema del Diritto Romano Attuale, v. III, trad. Scialoja, § 140, p. 406, Unione TipograficoEditrice, Torino, 1891.

6. Legislation Romaine, tomo II, $12^{\mathrm{a}}$ ed., n. 99, p. 80, Librairie Plon, Paris, 1883.

7. Tipografia all' Insegna dell' Ancora, Siena, 1889. 
“... esse consensus, que facit nuptias, não é de considerar-se no sentido ordinário da palavra consentimento, acordo momentâneo de duas vontades que produz um vínculo obrigatório perene, que se conserva tal ainda que aquelas vontades se tornem depois discordantes, como nos contratos em geral, os quais têm por precípuo escopo o de assegurar o intercâmbio dos serviços humanos contra a mutabilidade do querer humano. De feito, o requerido pelas nuptiae é um consentimento consistente num acordo de vontades não-instantâneo, mas continuado, com efeito limitado no tempo à sua própria duração. É sem dúvida por essa sua continuidade principalmente que ele concretamente assume natureza e denominação de affectus, affectio (maritalis uxoris).

Ora, essa affectio, essa vontade que dova existência e mantinha o matrimônio, encontra sua expressão no fato mesmo da comunhão de vida, por meio da qual ela dova contínua prova de sua permanência",8

Antes de Manenti, Scheurl ${ }^{9}$ e Maynz ${ }^{10}$ já haviam, embora de maneira vaga, formulado concepção semelhante, sem procurar, no entanto, desenvolvê-la. Labbé, em 1883, em escrito De la nature du mariage-que publicou em apêndice ao v. II da Explication Historique des Instituts de I'Empereur Justinien (Législation Romaine) ${ }^{11}$-, já havia chegado, sem limitá-las ao período justinianeu, a conclusões análogas, trazendo vários argumentos para corroborá-las; assim, definia o casamento

8. Ob. cit., § 15 , p. $42-3$.

9. Cfe. Orestano, La Struttura Giuridica del Matrimonio Romano dal Diritto Classico al Diritto Giustinianeo, v. I, p. 57-8, A. Giuffrè Editore, Milano, 1951.

10. Orestano ( ob. cit., I, p. 59, nota 163 ), que consultou apenas os Elements de Droit Romain (edição de 1855 ) de Maynz, nega-lhe equivocamente essa precedência. São de Maynz estas palavras: "Non, le mariage n'est pas un contrat donnant naissance à une obligation juridique: c'est une condition civile, impliquant un état de choses fondé sur l'union, la coniunctio, le consortium des parties. Ainsi, il ne suffit pas d'une manifestation quelconque de volonté pour créer le lien conjugal; il faut que l'intention des parties soit conforme à l'etat de fait" (Cours de Droit Romain, III, $5^{\mathrm{a}}$ ed., $\S$ 306, p. 12, nota 2, Bruxelles - Paris, 1891).

11. $12^{\mathrm{a}}$ ed., p. 684-7, Librairie Plon, 1883. 
romano como "um estado, uma maneira de viver, uma relação contínua entre duas pessoas, um hábito de vida comum (consuetudo uitae), que se estabelece voluntariamente entre um homem e uma mulher, estado em que o homem comunica à mulher as honras, a consideração e a dignidade social de que é cercado", ${ }^{12}$ acentuando, pouco adiante, que "o casamento não se forma num dado momento como um contrato; não, ele supõe condições múltiplas que podem realizar-se umas após outras e chegar, em seguida, a concorrer em conjunto" ${ }^{13}$ daí porque "ele começa a existir pela reunião dessas condições; ele se prolonga por sua permanência; ele se dissolve pela cessação de uma delas" ${ }_{14}^{14}$ o que leva a concluir:

"O casamento é, pois, um estado de fato que supõe a reunião e a permanência de um certo número de condições. A condição primeira é a vontade comum dos esposos, vontade realizada de viver como marido $e$ mulher. Que ocorrerá ao casamento, se um dos cônjuges cair em estado de demência? Não parece que o casamento deve cessar, porque um dos esposos não tem mais vontade? Semelhante questão não se levantaria a propósito de um contrato. Uma vez formado, ele produz seus efeitos, não obstante uma mudança no estado das vontades que, acordes um dia, constituiram $e$ vincularam definitivamente as obrigações. $O$ casamento não é um contrato, é um estado duradouro. Na espécie, a solução que prevaleceu é a de que o matrimônio subsiste apesar da loucura superveniente de um dos cônjuges. O motivo que Ulpiano dá para isso é digno de nota e confirma nossa maneira de ver: Retinetur matrimonium...quasi uoluntatis reliquiis in furiosis manentibus. A vontade anterior à loucura se torna

12. P 685

13. P. 685

14. P. 685 
latente; ela não cessa; ela não é substituída por uma vontade contrária ${ }^{, 15}$

A concepção de Manenti teve, contudo, a fortuna - que não tiveram seus predecessores de chamar a atenção de Bonfante. O próprio Manenti não tinha consciência da revolução que suas palavras desencadeariam no campo da dogmática do casamento romano. Sua tese limitava-se ao matrimônio no período justinianeu. Demais, continuava a considerar o casamento como relação jurídica, distinguindo o matrimônio cum manu do matrimônio sine manu, para reconhecer que, naquele, o casamento surgia de um ato jurídico formal. A idéia do consentimento contínuo, porém, estava lançada e germinaria rápido.

$O$ verdadeiro estruturador do que geralmente se denomina teoria de Manenti foi Bonfante, que, em 1896, na primeira edição de suas Instituzioni di Diritto Romano, ${ }^{16}$ expôs, já perfeitamente delineada, a nova concepção da natureza jurídica do casamento romano. Dois são os seus requisitos: a convivência e a intenção marital (affectio maritalis). A convivência a vida comum é o elemento objetivo; a affectio maritalis, o requisito subjetivo. No matrimônio, o consentimento - ao contrário do que ocorre nos contratos - não é inicial, mas duradouro, contínuo, preferindo os romanos, para designá-lo, a expressão affectio. Sua existência se comprova pela declaração dos cônjuges, parentes e amigos, ou, principalmente, mediante sua manifestação exterior o honor matrimonii, que é o tratarem-se marido e mulher como tais, em sociedade, razão por que se presume a existência de casamento quando a vida em comum com mulher livre e honrada. Concorrendo ambos os requisitos, surge o matrimônio; na falta de um deles, dissolve-se. Por isso, em Roma, inexistem formas jurídicas, não só para sua celebração, mas também para sua dissolução; e, por isso também é simples relação jurídica de mero fato, que perdura enquanto persistem as condições de fato convivência e affectio maritalis de sua existência.

Essas, as linhas fundamentais da nova teoria.

Desde o início, contudo, começaram a surgir restrições.

Se Manenti, ao aludir aos requisitos constitutivos de casamento se referia apenas ao direito no tempo de Justiniano, a teoria estruturada por Bonfante se

15. P. 686.

16. §58, p. 137-40, G. Barberà Editore, Firenze, 1896. 
aplicava ao matrimônio em qualquer dos períodos de evolução do Direito Romano do primitivo ao justinianeu. Contra essa extensão, manifestou-se Ferrini, em 1900, no Manuale di Pandette. ${ }^{17}$ Aí, salientou ele, que no direito clássico, à semelhança do que ocorre na posse, para que se constitua o casamento é necessário que, além do animus (A maritalis affectio a vontade atual de viver em comum, para formar uma família), a mulher seja colocada à disposição do marido (deductio in domum mariti). A influência do Cristianismo, no entanto, fez-se sentir fortemente sobre a essência do matrimônio, resultando disso que, no conceito cristão, o casamento "não é só uma relação que se desenvolve com o perdurar da maritalis affectio, mas é um ato pelo qual as duas partes se ligam e se vinculam para o futuro" ${ }^{18} \mathrm{Um}$ ano mais tarde, no artigo Sulla invalidazione sucessiva dei negozi giuridici, ${ }^{19}$ Ferrini precisou melhor sua tese, distinguindo, quanto à transformação do conceito de matrimônio, não mais direito clássico e cristão, mas pré-justinianeu e justinianeu. Naquele - e principalmente no período clássico -, o casamento perdura enquanto existe a maritalis affectio (a atual intenção de viver em matrimônio, e não consentimento inicial de que decorra vínculo para o futuro); neste, embora sem total coerência, o casamento passa a considerar-se "um ato inicial de consentimento, com o qual as partes criam um vínculo reciproco e duradouro" 20 motivo por que aqueles requisitos que, antes, deveriam existir durante todo o tempo em que perdurasse $o$ matrimônio, são, agora, exigidos somente para o ato inicial.

A tese de Ferrini, a príncípio, não encontrou eco na doutrina. Só vários anos depois, na década de trinta, foi retomada por Volterra, ${ }^{21}$ que, além de trazer em sua defesa, vários argumentos novos, sustentou ter a transformação de conceito clássico do casamento (cuja existência aí se fundava só na affectio maritalis) ocorrido a partir de Constantino. É certo, por outro lado, que Justiniano, no Corpus Iuris Ciuilis, aparentemente conservou as regras clássicas. Mas, aparentemente, pois o que, em realidade, ocorreu foi a completa modificação de sentido dos textos

17. N. 709, p. 682-3 (a citação se faz pela $4^{4}$ ed., Società Editrice Libraria, Milano, 1953).

18. Ob. cit., n. 709, p. 683.

19. In Opere di Contardo Ferrini, v. III, p. 357-83, Ulrico Hoepli, Milano, 1929

20. P. 378.

21. Seu pensamento, a propósito, que já se encontra em trabalhos anteriores, está condensado em La Conception du Mariage d'après les Juristes Romains, p. 33 e ss., Tipografia Editrice "La Garangola", Padova, 1940. 
clássicos. Com as mesmas palavras, as regras clássicas passaram a ter outro significado. Assim, affectio, ao invés de consentimento contínuo, indica, no direito justinianeu, acordo inicial de vontades. D'Ercole ${ }^{22}$ seguiu essa orientação. Voci, mais recentemente, sustenta que o casamento romano sofreu modificação de conceito nos três períodos de evolução do Direito Romano: na fase primitiva, está em harmonia com a estrutura familiar que é comunidade perpétua e solidária, o que faz com que o vínculo matrimonial seja subtraído da livre disponibilidade dos cônjuges (só se admitem algumas justas causas para o repúdio por parte do marido), podendo o casamento, nesse período, ser definido como "união tendencialmente perpétua, que, com o escopo da continuação da família, faz entrar a mulher na comunidade familiar religiosa do marido, e a submete ao poder deste (não absoluto, mas funcional)"; ${ }^{23}$ no direito clássico o panorama se modifica, pois, já no século I a. C., ele deriva da vontade dos cônjuges de serem e de se considerarem marido e mulher (affectio maritalis vontade que, além de inicial, deve ser permanente, mas que não está vinculada a nenhum requisito rigoroso de conveniência), o que importa relação de igualdade entre os cônjuges, cessando quando desaparece a affectio maritalis em um deles, e não mais introduzindo a mulher na família do marido por tudo isso, pode ser assim conceituado: "união do homen e da mulher com a intenção de ser marido e mulher"; ${ }^{24} \mathrm{e}$, no direito pós clássico, inspirando-se em idéias diversas impregnadas de influência cristã, passa a ser concebido como vínculo que não pode ser deixado à livre disponibilidade dos cônjuges (daí, a série de graves limitações ao divórcio), rompendo-se o equilíbrio entre a vontade inicial e a permanente em favor da primeira, e se tornando muito árdua sua definição, pois, de um lado, é abandonado o regime antigo, e, de outro, não surge um novo que seja coerente em seus elementos (não se rege pela exclusiva vontade inicial dos cônjuges, que cria um vínculo indissolúvel; pressupõe, ainda, vontade permanente, só se limitando a impor indiretamente a indissolubilidade, que não se concebe como regra inderrogável).

Por outro lado, em 1929, Albertario, ${ }^{25}$ sem se afastar radicalmente da teoria que encontrava suas raízes em Manenti, sustentou inspirado, sem dúvida,

22. Il Consenso degli sposi e la perpetuità del matrimonio nel Diritto Romano e nei Padri della Chiesa, in Studia et Documenta Historiae et Iuris, ano V (1939), p. 18 e ss.

23. Istituzioni di Diritto Romano, $3^{\text {a }}$ ed., $\S 135$, p. 464, Dott. A. Giuffrè Editore, Milano, 1954.

24. Ob. cit., p. 468.

25. Honor matrimonii e Affectio Maritalis, in Studi di Diritto Romano, I, p. 197-210, A. Giuffrè Editore, Milano, 1933. 
nas idéias de Levy, expostas no Der Hergang der romischen Ehescheindung, publicado em 1925 - que a determinação da permanência do casamento e da sua distinção do concubinato variaram no direito clássico e no direito pós-clássico justinianeu: naquele, a pedra de toque para a solução de ambos os problemas era a existência do honor matrimonii (comportamento exterior dos cônjuges como marido e mulher); neste, ao invés de se pesquisar o elemento exterior, buscava-se determinar a ocorrência, ou não, de elemento interior (affectio maritalis), o que implica dizer que neste período, o honor matrimonii é substituído pela affectio maritalis. Essa tese, que Albertario voltou a defender em L'autonomia dell'elemento spirituale nel matrimonio e nel possesso romano-giustinianeo e em Di alcuni riferimenti al matrimonio e al possesso in Sant'Agostino, ${ }^{26}$ foi largamente criticada pela maioria dos romancistas.

De 1940 a 1951, Orestano publicou, no Bullettino dell'Istituto di Diritto Romano, três estudos - parte de uma obra unitária mas não concluída que reuniu em livro intitulado La Strutura Giuridica del Matrimonio Romano, v. I, onde atacou vigorosamente a tese, que vem de Bonfante, de que um dos dois elementos constitutivos do casamento romano é convivência. Para ele, o matrimônio existe desde que haja a affectio maritalis objetivada, do direito clássico ao direito justinianeu, por elementos exteriores (os ritos nupciais, a convivência, o dote, as escrituras dotais, os esponsais, as declarações públicas) que exprimem todos pela expressão honor matrimonii. Demonstrou Orestano que, nas fontes, não há a menor alusão a que, na falta de convivência, cesse o casamento. Demais, são várias as hipóteses em que o matrimônio subsiste, apesar de inexistir a convivência, como sucede com relação ao casamento dos soldados, do absens, do prisoneiro de piratas ou bandidos. Aliás, os próprios seguidores da teoria de Bonfante já procuravam afastar esses obstáculos à sua tese acentuando que a convivência não se deveria entender em sentido material, mas, sim, idéia, ético, ao que objetou Orestano que "quando o problema vem colocado nesses termos, da convivência não resta senão a palavra" ${ }^{27}$

Ataque radical à concepção do casamento romano derivada da obra de Manenti moveu Piero Rasi, em 1946, no livro Consensus facit nuptias ${ }^{28}$ Nele,

26. In Studi di Diritto Romano, I, p. 213-28 e 231-47, respectivamente.

27. P. 99.

28. Dott. Giuffrè Editore, Milano, 1946. 
procurou demonstrar que, ao contrário do que pretende a maioria dos autores modernos, o matrimônio, também no Direito Romano clássico, era um uinculum iuris (vínculo de direito), sendo correta, portanto, a interpretação que glosadores e canonistas davam à expressão consensus facit nuptias. Em seguida à critica, passa Rasi a apresentar sua tese sobre natureza jurídica do casamento romano. Em Roma, a relação matrimonial nascia de uma stipulatio, que, como forma abstrata, podia dar eficácia a qualquer espécie de convenção. As fontes não aludem a essa stipulatio, mas os indícios de sua existência são vários. Por outro lado, a evolução dela, no Direito Romano, se reflete no matrimônio: também nele, quando a stipulatio perde a característica da oralidade e as formas rígidas caem em desuso, o escrito passa a ter importância, razão por que o vulgo começa a considerar necessárias ad substantiam as tabulaes (são as tabulaes nuptiales), nas quais, além da constituição de Maiorano declara essas tabulae indispensáveis à existência do casamento. No período pósclássico, o matrimônio é considerado contractus qui consensu perficitur (contrato que se aperfeiçoa com o consentimento), dependendo, pois, apenas do consentimento dos nubentes. É só nas últimas novelas de Justiniano é que se verifica forte reação em favor da forma.

As teses polêmicas de Piero Rasi não ficariam sem resposta. Ela veio em forma de recensio. Seu autor, Volterra ${ }^{29}$ A crítica foi cáustica, implacável, impiedosa. Chegou a tal ponto que o próprio Volterra procurou justificar-se de tanto rigor. As conjecturas de Rasi sobre a manus, no Direito Romano primitivo, e sobre a formação do casamento pela stipulatio foram os pontos mais mordazmente criticados. E, analisando o ataque à teoria de Manenti, salienta Volterra entre referências a erros de várias espécie - que Rasi não demonstrou a diferença de significado, que afirma existir, entre consensus (consentimento inicial) e affectio (sentimento, amor). Demais, acentua Volterra que "ainda que admitido e não concebido que o termo tivesse o significado de consentimento inicial (as fontes não o demonstram absolutamente), o uso dele não excluiria de forma alguma a nossa tese que quer o matrimônio fundado no consentimento contínuo, efetivo dos cônjuges" ${ }^{30}$ e isso porque o início do matrimônio coincide com o momento do consentimento. E conclui Volterra "o fato de os próprios juristas, quando deviam

29. Essa recensio foi publicada na Rivista Italiana per le Scienze Giuridiche, série III, anno I (1947), p. 399-412.

30. P. 407. 
determinar, ao contrário, se o casamento perdurava ou não não se referiam ao consentimento inicial, mas ao honor matrimonii e aos outros elementos exteriores, dos quais se podia inferir a existência da maritalis affectio, que exclui decididamente a teoria de Rasi e confirma, ao contrário, a teoria que ele entende combater" ${ }^{31}$

Em 1958, Rasi, no livro La Conclusione del Matrimonio nella Dottrina Prima del Concillio di Trento ${ }^{32}$, reconheceu que errara ao sustentar que os juristas romanos haviam regulado o casamento, explicitamente, como relação nascida de um contrato, mas perseverou no entendimento de que os opositores não estão certo quando pensam que os jurisconsultos romanos disciplinaram o matrimônio como relação de fato, que depende de uma uoluntas, ou de um honor, que se renova a todo instante. Em seu entender, os juristas romanos não enfrentaram, pelo menos no que nos chegou de suas obras, esse problema teórico, prescindindo de qualquer elaboração científica, e se adstringindo a resolver as questões que surgiam com a única preocupação de que suas soluções não contrastassem com os costumes, razão por que esses textos podem servir a interpretações em apoio das teses que atualmente se contrapõem, sem que permitam chegar-se a uma solução definitiva. Por isso, conclui que, para resolver-se o problema, seria indispensável que se examinasse o casamento romano em sua atuação prática, a fim de ver como era considerado pelos próprios nubentes, e como os costumes o regulavam - o que seria possível "trabalhando sobre fontes não-jurídicas, sejam literárias ou documentais", ${ }^{33}$ para depois, "num segundo momento, ir às fontes jurídicas $e$ interpretar as decisões que ai se encontram sem forçar os textos num sentido ou noutro" ${ }^{34}$ Estrada difícil de percorrer, observou Rasi, e talvez até impossível de fazê-lo, não tanto pela escassez das fontes, mas pelo fato de elas apenas se interessarem com a exterioridade da relação matrimonial, silenciando sobre os elementos necessários à sua formação e sobre as causas que, juridicamente, justificam sua extinção.

Atualmente, em face, principalmente, dos trabalhos de Volterra e de Orestano, os romanistas se inclinam no sentido de que, a partir de Constantino, o

31. P. 407.

32. Cas Editrice Dott. Eugenio Jovene, Napoli, 1958.

33. P. 11.

34. P. 11. 
casamento romano era um uinculum decorrente do consentimento inicial dos nubentes (como ocorre em nossos dias), e não mais uma relação de fato que perdurava enquanto persistisse o seu consenso (a affectio maritalis); ademais, já no direito clássico, para que essa relação perdurasse não se exigia a convivência dos cônjuges, bastando o consentimento continuado.

A isto, pois, se reduz a concepção de matrimônio romano resultante da obra de Manenti: o casamento, no período clássico, era uma relação de fato, que surgia com o consentimento dos nubentes e persistia enquanto ele perdurasse, extinguindo-se no momento em que essa affectio deixasse, realmente, de existir.

2. Será correta essa tese? De há muito sustentamos que não.

Já em 1959, em tese de concurso para a obtenção da livre-docência de Direito Romano na então Faculdade Nacional de Direito da Universidade do Brasil, vivamente impressionado pela parte crítica da obra de Rasi, acentuamos que "o matrimônio, no Direito Romano, foi sempre um ato jurídico, surgindo, assim, do consentimento inicial que gera um uinculum iuris, e prescindindo da vontade contínua que dá vida a um estado de fato" 35

Posteriormente, desde a primeira edição, em 1966, de nosso segundo volume do Direito Romano, demos, em nota, maior precisão a nosso pensamento:

" $A$ diferença que existe entre o casamento moderno $e$ o romano é esta:

no direito moderno, em geral, o casamento surge através de ato consensual rigidamente solene, celebrado diante de autoridade competente; e só se dissolve, por via de regra, pela morte, ou nos paises que o admitem pelo divórcio (e, ai, desde que se verifique um dos motivos previstos taxativamente em lei); em vista disso, a "relação jurídica matrimônio" uma vez surgida, não pode dissolver-se, sem mais, pela simples vontade de um dos cônjuges - daí, falar-se, apropriadamente, em vínculo conjugal;

35. Os efeitos da boa-fé no casamento nulo, segundo o Direito Romano, p. 8, Rio de Janeiro, 1959. 
- no Direito Romano, não: para que surgisse o casamento, bastava a vontade inicial ("consensus") dos nubentes, sem quaisquer formalidades (apenas a partir do direito pós-clássico é que, em algumas hipóteses vide o n. 291 -, se exige certo formalismo), e o matrimônio perdurava até que um dos cônjuges desejasse rompê-lo, pois - como veremos adiante (no $n$. 295), em Roma, sempre se admitiu divórcio por vontade unilateral (mesmo no direito justinianeu, se um dos cônjuges repudiasse o outro sem motivo, ele poderia sofrer sanções, mas o casamento se dissolvia), a qualquer tempo, sem formalismo, $e$ independente da existência de motivos fixados, previamente, em lei - daí, a expressão "affectio maritalis" para significar, não que fosse necessário que os cônjuges tivessem a intenção contínua (idêntica à vontade inicial) de serem marido $e$ mulher, mas que o casamento perdurava enquanto eles (ou um deles) não praticassem ato contrário ao que dera início ao matrimônio: o divórcio.

Em favor dessa tese - que afasta os elementos objetivo (convivência, vida em comum) e subjetivo (affectio maritalis - vontade contínua), e que só considera como requisito para a existência do casamento o consentimento inicial dos nubentes que tenham entre si conubium -, podemos arrolar, entre outras (pois o caráter desta obra não permite maiores digressões a respeito), as seguintes circunstâncias:

a) também com relação ao contrato de sociedade (que não se pode pretender fôsse uma relação de fato dependente de vontade contínua dos sócios), os textos usam de expressões como affectio societatis, si in eadem uoluntate perseuerat (se persevera na mesma vontade), manet autem societas eo usque, donec in eodem consensu perseuerant (a sociedade persiste por tanto tempo quanto persevera íntegro o consentimento das partes) e isso porque, como ocorria com o casamento, o contrato de sociedade podia extinguir-se, a qualquer tempo, pela vontade unilateral dos sócios (vide n. 244, in fine), e, conseqüentemente, só perdurava enquanto todos o desejassem; 
b) o louco, no Direito Romano, não podia casar-se, por estar impossibilitado de manifestar o consentimento inicial, mas - salientam os textos (assim, por exemplo, Paulo, Sententiarum ad filium libri, II, 19, 7; e D. 1, 6, 8, pr.) se a loucura surgir depois de contraído o matrimônio, este, apesar dela, perdurava, o que demonstra inequivocamente que o pretenso consentimento contínuo (affectio maritalis) não era requisito para a existência do casamento, pois requisito (ou elemento essencial) é aquele sem o qual não há o ato, e, em conseqüência, não admite exceções; por outro lado, não se pretenda afirmar que, se a vontade contínua não fosse elemento essencial do casamento, os juristas romanos não se preocupariam em excetuar a hipótese do louco e não pretenda isso, porque os jurisconsultos romanos, até com relação ao direito de propriedade (e ninguém assevera que o proprietário tem de ter a vontade contínua de sê-lo), diziam que continuava o louco a ser titular desse direito:

"Qui furere coepit, et statum et ignitatem in qua fuit et magistratum et potestatem uidetur retinere, sicut rei suae dominium retinet" (D. 1,5,20); $\mathrm{e}$

c) há textos (D. 24, 2, 7; e 24, 3, 2) que declaram, taxativamente, que embora um dos cônjuges tenha enviado o libellus diuortii ao outro, se houver arrependimento dentro de breve espaço de tempo, o casamento - apesar da ausência da affectio maritalis, ao menos no momento em que um deles remeteu o libellus diuortii - persiste; princípio esse que é incompatível com a tese da affectio maritalis.

Note-se, aliás, que Perozzi (Istituzioni di Diritto Romano, I, $2^{\mathrm{a}}$ ed. reintegrazione 1949 -, $\S 39$, p. 324 e ss.), depois de afirmar que o casamento romano é um status, salienta que não há requisito para sua conservação, mas apenas para seu nascimento e para sua dissolução; e mais: que o casamento persiste ainda que haja ausência de vontade (como na hipótese de louco), só se dissolvendo (além, obviamente, da circunstância de morte) se há vontade contrária a que ele perdure" 36

3. Em 1970, Robleda ${ }^{37}$ suscitou dúvidas sobre a doutrina do consentimento contínuo, no Direito Romano clássico, e procurou demonstrar que os argumentos de Volterra para sustentá-la se conciliam com a tese de que o

36. Direito Romano, p. 350-2, nota 735, Editor Borsai, Rio de Janeiro, 1966.

37. El Matrimonio en Derecho Romano, p. 130-44, Università Gregoriana Editrice, Roma, 1970. 
matrimônio, no Direito Romano clássico, surgia do consentimento inicial dos nubentes, sem quaisquer formalidades, não dependia da persistência dele (affectio maritalis), e só extinguia por ato contrário, o divórcio, que independia de causa e de forma, podendo ser demonstrado por qualquer meio de prova. Observou Robleda que a circunstância de, automaticamente, transformar-se em justas núpcias a união contraída com algum obstáculo, desde que este cessasse e perseverasse o consensus, é fórmula que se encontra no Codex iuris canonici (c. 1139), e isso não obstante "um canonista não deduzirá daqui a continuidade do consentimento, acima descrita; todos pensam antes, no consentimento próprio de um pacto que conserva sua virtualidade, enquanto não se revogue com ato contrário", ${ }^{38}$ que os textos que mostram que a existência do consentimento se pode deduzir de fatos habituais se explicam, sem necessidade da tese do consentimento continuado, como permitindo quaisquer meios de prova de consentimento inicial não revogado, tanto assim que esses textos se encontram no Corpus Iuris Ciuilis, e o próprio Volterra reconhece que no tempo de Justiniano não mais havia o requisito do consentimento continuado; que a plena liberdade de divórcio indica, apenas, que, no direito clássico, não havia formas solenes ou causas de divórcio, mas era preciso, qualquer que fosse o modo de provê-lo, ato contrário e sua manifestação; e que o fato de o segundo casamento poder importar divórcio com relação ao matrimônio anterior não significa que este extinguisse aquele por cessação do consentimento contínuo, mas que o segundo casamento podia substituir ou confirmar declaração de divórcio feita pelo repudium (comunicação expressa, por escrito ou oralmente, de vontade contrária). Por outro lado, pela necessidade de consentimento positivo contrário ao inicial e não pela mera cessação de consentimento contínuo (pelo qual o casamento se perfaz a cada momento), explica-se a razão por que o casamento não se extinguia por loucura superveniente $\mathrm{e}^{39}$ e o motivo pela qual a superveniência de impedimento, por vezes dissolvia o casamento anterior, por vezes não o extinguia (o extinguir-se, ou não, não decorria da concepção de consentimento contínuo, mas, sim, da vontade da lei: o consentimento inicial criava um vínculo que a disciplina legal rompia, como resulta do C. $5,4,28,2$ e 3$)^{40}$

38. Ob. cit., p. 132.

39. D. I., 6, 8, pr.; D. 23, 2, 16, 1; D. 24, 2, 4; Paul. Sent. 2, $19,7$.

40. "Taceat Papiae legis crudelissima santio et neque per hunc modum dissoluatur matrimonium" 
O valor dessas objeções - que já tinham sido objeto de crítica de Disalvio, ${ }^{41}$ e a que Robleda ${ }^{42}$ não deixou sem resposta - fez que Volterra considerasse necessário enfrentá-las. Em 1975, publicou ele, no volume XVII da terceira série do Bullettino dell'Istituto di Diritto Romano "Vittorio Scialoja", ${ }^{43}$ o artigo Precisazioni in tema di matrimonio classico, onde, depois de sintetizar as dúvidas levantadas, por Robleda, procurou demonstrar que, partindo do pressuposto de que, para os juristas romanos clássicos, o casamento só existia com a presença de três requisitos positivos (a idade dos esposos, o conubium entre eles e a existência de vontade atual dos cônjuges, aferível por meio de qualquer elemento direto ou indireto, de quererem estar reciprocamente unidos em relação conjugal legítima). "é fácil verificar como o exame das doutas observações de Robleda confirma a noção que delineamos do casamento clássico e contribuem para precisá-la e para aprofundar a interpretação das fontes" ${ }^{44}$ Analisa em seguida, um a um, os argumentos apresentados por Robleda. Observa, inicialmente, que, sendo diversas as concepções de matrimônio no Direito Romano clássico e no Direito Canônico, não se pode invocar o canon 1139 do Codex Iuris Canonici para estabelecer paralelo entre elas. Acentua, em seguida, que não the parece que a famosa passagem de Modestino (D. 23, 2, 24 "In liberae mulieris consuetudine non concubinatus, sed nuptiae intelligendae sunt, si non corpore quaestum fecerit") possa ser entendida de outro modo que não no sentido de que a habitual convivência com mulher livre, que não seja dada à prostituição, deva ser interpretada (desde que subsistam os outros elementos: a idade e o concubium) como iustae nuptiae e não como concubinato; e não se vê como se possa extrair das palavras do jurista romano a existência de um consentimento inicial não revogado. Nega, também, a tese de que, para a cessação do casamento, fosse necessário ato contrário de vontade devidamente manifestado, ainda que por parte de um só dos cônjuges, pois das fontes lhe parece deduzir-se que o casamento deixaria de existir no momento em que não subsistisse o concubium ou consentimento continuado dos esposos, sendo que, quanto a esse último, sua inexistência seria aferível por qualquer fato ou comportamento direto ou indireto.

41. Matrimonio e Diritto Romano, in Index, v. II (1971), p. 376-86.

42. Sobre el matrimonio in Derecho Romano, in Studia et Documenta Historiae et luris, v. XXXVII (1971), p. 337-50.

43. P. $245-70$.

44. Ob. cit., p. 252 
Ademais, no tocante aos textos relativos à persistência do casamento apesar da loucura superveniente, procura demonstrar que o exame mais aprofundado desses textos se concilia com a concepção de casamento que sustenta para o Direito Romano clássico; afastando as duas sintéticas afirmações de Paulo, examina os dois textos (D. 24, 2; e D. 1, 6, 8) em que Ulpiano decide, a respeito, questões práticas, e salienta que, quanto ao primeiro, a circunstância de a louca poder ser repudiada, uma vez que ela ignorantis loco habetur (se tem como carecedora de conhecimento), demonstra que basta a cessação de vontade de um só dos cônjuges, sem a do outro, para romper o vínculo conjugal, e vontade essa que, no caso, é do esposo são, como resulta da frase pouco clara: quod non tractaret de repudio, nisi constaret retineri matrimonium; e, no concernente ao segundo texto, anota que dele se verifica que o casamento persiste porque se considerava que permanecia a vontade do demente (uoluntatis reliquis in furiosis manentibus), conclusão, aliás, que se ajustava à noção romana de doenças mentais (os furiosi, ao contrário dos mente capti, não eram atacados de mal incurável, mas somente temporário), e que correspondia, também, ao raciocínio dos juristas clássicos para decidir que persistia a posse furiosus (D. 41, 2, 27: quia furiosus non potest desinere animo possidere porque o louco não si pode perder a intenção de possuir). Por outro lado, no que diz respeito aos textos que aludem à formação de um segundo casamento se referem a repúdio prévio (assim, Cícero, De oratore, I, 40, 183 e I, 56, 238, e Gaio, I, 63), detém-se Volterra na análise de uma constituição de Valeriano e Galieno que é reproduzida em duas passagens do Código (C. 5, 3, 5; e C. 9, 9, 18), sustentando que, na hipótese examinada por essa constituição, o primeiro casamento persistia exclusivamente porque o segundo não demonstrava que o homem tivesse a intenção de desfazer 0 primeiro, tanto assim que, para contrair aquele, se apresentara como solteiro (ficto coelibatu), persistência essa que impedia que constituísse validamente o segundo matrimônio, em conformidade, aliás, com a concepção da necessidade do consentimento continuado. Acrescenta, ainda, Volterra que nem sequer o texto de Quintiliano - Decl., 347, 8 (9) - se contrapõe a essa concepçãr, pois, não obstante o marido tido como morto matasse, como adúltera, a mulher que contraíra novas núpcias, sob a alegação de que o casamento anterior persistia, visto como não fora extinto pelo repúdio ou pela morte de um dos cônjuges, do exame de toda a declamatio se verifica que "o princípio que o marido invoca para excusar-se do crime de homicídio é conforme ao princípio monogâmico romano e não exclui, absolutamente, de quanto resulta das passagens citadas de Cícero e dos juristas, 
que o matrimônio pode ser extinto com a cessação da vontade continuada ainda que de um só dos cônjuges" ${ }^{45}$; o ponto central da defesa do marido assassino estaria em demonstar que este, ao matar, acreditava que seu casamento perdurava, não tendo conhecimento do segundo e parecendo, exteriormente, não mudada sua condição conjugal. E, ao encerrar esse artigo, Volterra, declarando que, graças a Bickerman, teve sua atenção despertada para a narração de Tácito (Anais, XI, 26 e segs.) do casamento de Messalina com Sílio, examina esse episódio, e conclui que, em seu entender, é um "decisivo testemunho literário antigo" da tese por ele sustentada ${ }^{46}$

Em 1977, Huber publicou, devidamente remanejada, a tese Der Ehekonsens im Romischen Recht, que apresentara, no semestre de inverno 1971/1972, à Universidade Gregoriana de Roma para a obtenção do título de do doutor em Direito Canônico. Nela, desenvolveu ele as objeções de Robleda à concepção de consentimento continuado no casamento romano clássico, o que deu margem à crítica de G. Longo, em artigo - "Ancora sul matrimonio romano (a proposito del volume de Josef Huber)" publicado em Studia et Documenta Historiae et Iuris. ${ }^{47}$

Voltou à carga Volterra, em trabalho ${ }^{48}$ que foi inserido no livro $D e$ Iustitia et Iure, Festgabe für Ulrich von Lübtow zum 80. Geburstag, ${ }^{49}$ e no qual, sentindo a necessidade de reforçar a defesa da concepção do consentimento contínuo, trouxe à discussão mais um texto (C. V. 17,6), que, segundo ele, tem sido interpretado diferentemente por não o terem os intérpretes examinado sob essa ótica.

Mais recentemente, em 1986, Pugliese, embora seguindo a teoria de Volterra, reconhece que o tratamento dado ao matrimônio do furiosus demonstra "o caráter não rigoroso da orientação jurisprudencial que exigia a vontade matrimonial contínua" ${ }^{50}$ Nesse mesmo sentido, manifestou-se, em 1989, Talamanca, que chega a dizer que "do que resulta das fontes parece que a categoria do consentimento continuado encobre uma realidade muito mais limitada" ${ }^{51}$

45. Ob. cit., p. 261

46. Ob. cit., p. 270

47. V. XLIII (1977), p. 459-80.

48. Ancora sulla struttura del matrimonio classico.

49. P. $147-53$.

50. Istituzioni di Diritto Romano, Parte Seconda, p. 429, Piccin, Padova, 1986.

51. Istituzioni di Diritto Romani, 1, n. 40, p. 140, Dott. A. Giuffrè Editore, Milano, 1989. 
4. Examinemos a longa defesa que, em 1975, fez Volterra de sua tese em face das observaçð̃es de Robleda.

Robleda, ao invocar o canon 1139, § 1, do Código Canônico quanto à necessidade da persistência do consentimento (dummodo consensu perseueret) para que se sanem vícios do casamento anteriormente contraído, o faz com o propósito de demonstrar que essa persistência pode ter no canon e ninguém nega que o casamento canônico resulta de consentimento inicial e não de consentimento continuado - o mesmo sentido dos textos romanos, ${ }^{52}$ ao acentuarem que, cessado o obstáculo ao casamento, este surge, se o casal in eadem uoluntate perseuerat (também no direito canônico, cessado o óbice ao casamento, não é necessário novo consentimento, se o anterior não foi revogado por ato contrário). Por isso - observa Robleda -, esses textos romanos continuaram válidos no direito pós-clássico, em que, como reconhece o próprio Volterra, se exigia, apenas, o consentimento inicial. Ora, para afastar essa objeção, seria mister que se demonstrasse que tais fontes romanas somente são compatíveis com a tese de que o casamento exige consentimento continuado, sendo ela prova inequívoca. Volterra tenta fazê-lo, observando que, pela concepção romana clássica, o matrimônio não se contrai mediante a só manifestação de vontade dos cônjuges sem que haja impedimento, mas as iustae nuptiae se apresentam como a união conjugal entre duas pessoas de sexo diverso com a subsistência atual dos requisitos positivos que são a idade mínima, o conubium e a vontade dos cônjuges, o que significa que sem um desses requisitos as iustae nuptiae não são consideradas nulas ou anuláveis, mas simplesmente inexistentes. Essa resposta teria peso se, no Direito Romano clássico, o consentimento inicial e o consentimento continuado, em matéria de casamento, não fossem ontologicamente diferentes, mas ao contrário, aquele fosse apenas o momento inicial deste. Não é isso, porém, o que ocorre. Com efeito, o alieni iuris, para contrair casamento, necessitava de que seu consentimento fosse completado pelo auctoritas do pater familias, como declaram os textos, genuinidade que ainda não foi abalada por tentativas de demonstrá-los interpolados: D. 23, 2, 2 ("Nuptiae consistere non possunt nisi consentiant omnes, id est qui coeunt quorumque in potestate sunt") e as Regras de Ulpiano 5, 2 ("Iustum matrimonium est, si inter eos, qui nuptias contrahunt, conubium sit, et tam masculus pubes quam femina uiri potens sit, et utrique consentiant, si sui iuris sint, aut etiam parentes eorum, si in potestate sint').

52. Assim, por exemplo, D. 23, 2, 65. 
Neste último, encontram-se reunidos os três requisitos que, segundo Volterra, seriam necessários para que o casamento fosse iustum. Ora, a auctoritas só se dá no momento inicial do matrimônio, como resulta de um texto incorreto, mas que traduz princípio clássico (Paulo, Sent. 2, 19, 2: "Eorum qui in potestate patris sunt sine uoluntate eius matrimonia iure non contrahuntur, sed contracta non soluuntur"). Não fora assim, e o casamento seria dissolvido se, a qualquer momento, a auctoritas fosse retirada, o que não encontra nenhum apoio nas fontes romanas. Portanto, para o objeção de Volterra ser correta, necessário se faria que também a auctoritas fosse continuada, pois somente dessa forma, no momento em que o conubium surgisse, o consentimento dos nubentes e a auctoritas a ele se reuniriam para que as iustae nuptiae, até então inexistentes, pudessem surgir. Sendo, ao contrário, a auctoritas inicial, o si in eadem uoluntate perseuerat a abarca, porque ela é requisito essencial das iustae nuptiae, esboroando-se, portanto, o engenhoso argumento de Volterra, o qual, ademais, já encontrava obstáculo na observação, de Robleda, de que os textos clássicos continuavam válidos no direito pós-clássico, quando o consentimento para o matrimônio era apenas o inicial. E - note-se - os próprios juristas clássicos empregavam expressão semelhante para traduzir a subsistência do consentimento inicial vinculante até a ocorrência de ato contrário a ele. É Gaio ${ }^{53}$ que, depois de colocar a societas entre os contratos consensuais, acentua: "manet autem societas eo usque, donec in eodem consensu perseuerant. At cum aliquis renuntiauerit societati, societas soluitur" Contrato que exige consentimento continuado? Evidente que não. Contrato que persiste enquanto qualquer das partes não pratica ato contrário: a renuntiatio. $\mathrm{O}$ mesmo, aliás, se dá na doação entre cônjuges, proibida nos fins da república, mas, de acordo com uma oratio ${ }^{54}$ de Sétimo Severo e de Caracalla (206 d. C.), tornada válida se o cônjuge doador morre sem tê-la revogado. Os textos, a propósito, aludem a in eadem uoluntate perseuerare ${ }^{55}$ ou a durante uoluntate ${ }^{56}$, ou, ainda, a durauerit uoluntas. ${ }^{57}$ Também, nesse caso, não há vontade continuada, mas, apenas, possibilidade de revogação, que só ocorre se o doador tiver manifestado em vida vontade de revogar a doação, como resulta, inequivocamente, de texto atribuído

53. Institutas $3,151$.

54. D. $24,1,32,1$ e 2 .

55. C. $5,16,1 ;$ C. $5,16,3$ (constituiçðes imperiais dos anos 212 e 213 , respectivamente).

56. D. $24,1,23$.

57. D. $24,1,32,22$. 
a Ulpiano (D. 24, 1, 32, 1 e segs.). O que implica dizer que há necessidade de ato contrário, como decorre, também, de constituiçð̌es imperiais de 229 e 291 d. C.. ${ }^{58}$

Por outro lado, é mera petição de princípio a resposta, de Volterra, de que não vê como se possa extrair das palavras de Modestino (D. 23, 2, 24 - "In liberae mulieris consuetudine non concubinatus, sed nuptiae intelligendae sunt, si non corpore quaestum fecerit') a existência de consentimento contratual inicial não revogado, sendo elas, ao contrário, prova inequívoca de que há necessidade, no momento em que se faz a verificação, do consentimento recíproco dos cônjuges. Esse texto, como bem acentua Robleda não demonstra necessariamente o caráter contínuo do consentimento, mas estabelece simples presunção de casamento, que se ajusta, igualmente, à concepção de que ele decorre de consentimento inicial e perdura enquanto não há divórcio, como, aliás, sucede com referência à presunção resultante, em sistemas jurídicos modernos, da posse do estado de casado. Tem também razão Robleda quando adverte que a plena liberdade de divorciar existente no Direito Romano clássico não se opõe à concepção de que, para dissolver-se o matrimônio, seria necessário ato contrário - ainda que independente de forma e de causa - ao que lhe dera início.

Menos convincente, ainda, é a resposta que Volterra pretende dar à argumentação de que a não-cessação do casamento em virtude da superveniência da loucura de um dos cônjuges é incompatível com o requisito do consentimento continuado, que pressupõe que o matrimônio se esteja realizando em cada momento, mas se ajusta perfeitamente ao entendimento de que o casamento romano clássico só se dissolve por ato positivo contrário ao consentimento inicial. Deixa Volterra de lado as duas afirmações atribuídas a Paulo - D. $23,2,16,1,{ }^{59}$ e Sent. $2,19,7^{60}$, por demasiado sintéticas, e se dispõe a demonstrar, do exame analítico das outras duas passagens citadas também por Robleda (D. 24, 2, 4 e D. 1, 6,8), que delas se pode retirar o pensamento dos juristas clássicos, o qual se ajusta à noção, por ele sustentada, de iustae nuptiae, e, portanto, à necessidade do consentimento continuado. Sucede, porém, que da análise do primeiro desses textos (D. 24,2,4), que diz respeito à questão, posta por Juliano, de saber se a esposa furiosa pode repudiar

58. C. $5,15,2$ e C. $5,16,15$.

59. "Furor contrahi matrimonium non sinit, quia consensu opus est, sed recte contractum non impedit"

60. "Neque furiosus neque furiosa matrimonium contrahere possunt, sed contractum matrimonium furore non tollitur" 
ou ser repudiada, Volterra, da frase final ("quod non tractaret de repudio, nisi constaret retineri matrimonium"), que reconhece pouco clara e decorrente talvez de imperfeição da tradição manuscrita, conclui que ela parece exprimir que "se pode falar de repúdio só se resulta que o matrimônio se conserva" ${ }^{\prime 61}$ o que "confirmaria o que decorre do início do fragmento: que a dissolução ou a manutenção do casamento depende da vontade do cônjuge que permanece são da mente" ${ }^{62}$ Ora, se essa frase final acentua que o casamento não se dissolve com a loucura, quer isso dizer que, para a sua manutenção, não se exige necessariamente a continuação da vontade de um dos cônjuges (o furiosus), o que é incompativel com a tese do consentimento contínuo, que pressupõe a permanência da vontade de ambos os cônjuges. Quanto ao segundo texto (D. I, 6,8), que concerne à patria potestas do furiosus, acentua Volterra, com base em duas passagens nele constantes "furiosus licet uxorem ducere non possit, retinere tamen matrimonium potest" e "quasi uoluntatis reliquiis in furiosis manentibus. Nam cum consistat matrimonium altero furente, consistet at utroque" -, que elas permitem a reconstrução do pensamento dos juristas clássicos, pois, da situação de fato dessa união conjugal não se evidenciava a cessação do consentimento recíproco, mas apenas a impossibilidade, da parte do demente, de formular e de exprimir direta ou indiretamente sua vontade, razão por que não se podia saber se teria cessado (uoluntatis reliquiis in furiosis manentibus) a vontade do demente ou do cônjuge são, conclusão que se impunha pela noção dos romanos sobre as doenças mentais: "os furiosi, diferentemente dos mente capti, não seriam atingidos por um mal incuróvel, mas somente temporário" ${ }^{63}$ Aliás prossegue Volterra -, esse raciocínio de Ulpiano corresponde ao dos juristas clássicos para afirmar a continuação da posse do furiosus (D. 41, 2, 27: quia furiosus non potest desinere animo possidere - "porque o louco não pode perder a intenção de possuir"). E arremata Volterra que, faltando nos textos citados, de modo absoluto, a consideração de que o casamento só permanece enquanto o cônjuge são ou o pater familias do demente não enviarem o repúdio ao outro, as decisões dos juristas quanto ao matrimônio do furiosus confirmam a tese da necessidade do consentimento continuado, pela qual a dissolução do casamento não depende de ato

61. Precisazioni in tema di matrimoni classico, in Bulletino dell'Istituto di Diritto Romano

"Vittorio Scialoja", v. XVII da terceira série, p. 255.

62. Idem, ibidem.

63. Idem, p. 257. 
contrário, mas basta "a verificação, com base em elementos diretos ou indiretos, da cessação do consentimento mesmo": ${ }^{64}$

Como se vê, o que, em síntese, Volterra pretende é que, para os juristas clássicos, como resulta da frase "quasi uoluntatis reliquiis in furiosis manentibus", o furiosus conservava "restos de vontade" e, graças a eles, o consentimento persistia, mantendo-se, pois, o casamento, o que ocorria também com relação à posse.

Sucede, porém, que, em primeiro lugar, Volterra deixa de responder à observação que Robleda, de antemão, fizera a respeito dessa mesma frase, ao escrever em nota à assertiva de que "o matrimônio não se dissolve pelo fato da demência, se bem que o demente haja cessado de querer seu casamento, ou seja, haja cessado de poder continuar a dar-lhe vida com a qualidade de consentimento que para isso requer": ${ }^{65}$

"Digo isso, porque aquelas uoluntatis reliquiae que Ulpiano diz permanecer no demente (quasi uoluntatis reliquiis in furiosis manentibus: D. $1,6,8$ pr.) evidentemente não bastem para dar vida ao matrimônio com seus direitos e obrigações. Se, pois, esses direitos e obrigação não houvessem surgido em virtude do consentimento inicial, e só devido a ele (inicial, nãorevogado) perseverassem, não se explicaria sua existência, uma vez que a partir do momento da demência a produção dos mesmos não se pode seriamente admitir" 66

Em segundo lugar, e ao contrário do que se dá com os textos que se contrapõem à sua concepção, não se preocupou Volterra em refutar a tese de Beseler $^{67}$, acolhida por Albertario ${ }^{68}$, de que as expressões quasi uoluntatis reliquiis

64. Idem, ibidem.

65. Ob. cit., p. 134.

66. Ob. cit., nota 196, p. 134-5.

67. Beiträge zur Kritik der romischen Rechtsquellen, II, p. 2, J. C. B. Mohr (Paul Siebeck), Tubingen, 1911.

68. Conceptus pro iam nato habetur, in Bullettino dell'Istituto di Diritto Romano, ano XXXIII, $\mathbf{p}$. 9 , nota 1 . 
in furiosis manentibus são interpoladas, sob o fundamento de que "quasi-manentibus não é somente um sofisma, mas não se ajusta à concatenação das idéias". Ademais, esse texto não se concilia com a parte genuína ${ }^{69}$ da passagem de Pompônio no D. 50, 17, 40 ("Furiosi ... nulla uoluntas est").

Em terceiro lugar, as afirmaçð̃es, de Volterra, de que os juristas clássicos "eram, portanto, induzidos a considerar que também a vontade do demente, como a do cônjuge são, não terminasse (uoluntatis reliquiis in furiosis manentibus) e, na verdade, que perdurasse o consenso e conseqüentemente o matrimônio" ${ }^{70}$ e que "esta conclusão, que se conciliava com a sua concepção de iustae nuptiae, se impunha também pelas suas noçð̃es sobre moléstias mentais, pelas quais consideravam que os furiosi, à diferença dos menti capiti, não fossem atingidos por mal incurável, mas que este fosse somente temporário" ${ }^{71}$ deixam de lado, inclusive, a circunstância de que é extremamente discutida a distinção, no direito clássico, entre furiosus e mente captus. Aliás, o próprio Volterra reconhece que "é controvertida entre os estudiosos qual fosse a noção jurídica do louco no Direito Romano"72, esclarecendo:

"Segundo alguns, dever-se-ia distinguir o furiosus do mente captus ou demens: o critério distintivo entre uns e outros estaria baseado no fato de que o furiosus tem lucidi interualli: os segundos, não. Para outros, os furiosi seriam os loucos agitados, ao passo que os mente capti seriam os fracos da mente. Uma terceira teoria que identificar a demência como a monomania. Alguns consideram que os compiladores justinianeus teriam introduzido o critério dos intervalos lúdicos para distinguir os furiosi dos mente capti" ${ }^{73}$

69. Cfe. Nardi, Squilibrio e Dificienza Mentale in Diritto Romano, p. 167, Dott. A. Giuffrè Editore, Milano, 1983.

70. Ob. cit., p. 256.

71. Ob. cit., p. 256-7.

72. Istituzione di Diritto Privato Romano, § 26, p. 111, Edizioni Ricerche, Roma, 1961.

73. Idem, ibidem. 
E, finalmente, em quarto lugar, no tocante à aproximação dessa questão com a da continuação da posse pelo furiosus (D. 41, 2, 27), porque este "non potest desinere animo possidere", é de considerar-se que esse texto não demonstra que, para a conservação da posse, era necessário o animus continuado (que pressupõe que tal elemento subjetivo persista com as características com que se iniciou), mas, sim, que a permanência da posse animo decorria apenas de não ter o louco vontade para deixar de possuir.

Quanto às observações de Robleda a respeito de que a dissolução do casamento, no período clássico, pela superveniência da captiuitas e a não-dissolução dele, no período pós-clássico, pela mesma causa, podem ser explicadas, também, pela mudança de disciplina jurídica nesses períodos, decorrente de motivos outros que não o da necessidade do consentimento continuado no período clássico e do consentimento inicial no período pós-clássico, Volterra, ${ }^{74}$ ao invés de procurar demonstrar que essa interpretação de Robleda é inadmissível, se adstringe a afirmar que, em seu entender, para os juristas clássicos a falta de conubium não era superveniência de impedimento que tornasse nulo o casamento romano, mas um dos casos de seu término por desaparecimento de um de seus elementos essenciais. Ora, Robleda não nega que essa possa ser uma das interpretações admissíveis - e interpretação que se estenderia ao elemento consentimento, para exigi-lo permanente -, mas acentua que isso, no direito clássico, em face mesmo dos textos, poderia decorrer de outras causas que não esta, o que, se é certo que não invalida a primeira interpretação, lhe tira a força de ser prova irresistível da necessidade do consentimento continuado para o casamento romano clássico.

5. O ponto, porém, em que me parece mais vulnerável a defesa de Volterra é o relativo aos textos jurídicos e literários referentes à não-dissolução do primeiro casamento pelo segundo. Não há dúvida alguma de que, para a teoria do consentimento continuado, é indispensável que o casamento posterior dissolva, sem divórcio ou repúdio prévios, o casamento anterior, pois, com aquele, cessa a continuação do consentimento que é elemento essencial deste. A recíproca, necessariamente, tem de ser verdadeira: o casamento anterior não pode impedir o casamento posterior; que apenas não passa a coexistir com ele, mas o extingue. Não

74. Precisazioni in tema di matrimonio classico, in Bullettino dell'Istituto di Diritto Romano "Vittorio Scialoja", v. XVII da terceira série, p. 257. 
fora assim, como é que o casamento posterior, sem mais, poderia extinguir o anterior, se este impedia que aquele surgisse?

Robleda, a esse respeito, não segue essa colocação lógica, porque dá por assente que tem razão Volterra, quando afirma que o segundo casamento podia implicar divórcio com relação ao anterior. Mas, na sua linha de levantar dúvidas ao acerto da tese do consentimento contínuo, sustenta que isso pode também ser argumento em favor de que o segundo casamento é tido como modo de substituir ou de confirmar o divórcio, por implicar vontade contrária à que lhe deu início, coadunando-se assim com a tese de que o casamento romano não exigia consentimento continuado, mas apenas consentimento inicial, que, para ser desfeito, necessitaria de vontade posterior a ele contrária, o que poderia decorrer também do segundo matrimônio.

Nesse ponto, todavia, a questão a enfrentar é a de saber qual das duas proposições seguintes - que se excluem reciprocamente - é a verdadeira: a existência do primeiro casamento impede que validamente surja o segundo; ou este implica a necessária dissolução daquele. Se verdadeira a primeira dessas proposições, constituirá ela objeção intransponível à teoria do consentimento contínuo; se a segunda, não implicará ela argumento decisivo para nenhuma das duas teses, pois a dissolução tanto pode resultar da cessação do consentimento continuado, quanto terse como conseqüência de o segundo matrimônio servir de modo de substituição ou de confirmação do divórcio.

Não há nenhum texto, jurídico ou extrajurídico, que declare que o casamento, no Direito Romano clássico, se dissolvia só pelo fato de um dos cônjuges contrair novo matrimônio. Ao contrário, no Digesto se encontra fragmento atribuído a Paulo (D. 24, 2, 1) que enumera as principais causas de dissolução do casamento ("Dirimitur matrimonium diuortio morte captivitate uel alia contingente seruitute utris eorum"), não incluindo entre elas a superveniência de novo casamento por um dos cônjuges. Como observa Orestano que retira de sua omissão sobre a conveniência dos cônjuges argumento de que esta não era requisito para a permanência do casamento romano , embora esse texto não esteja imune à suspeita de interpolação, não parece fácil explicar a razão por que, se os juristas justinianeus o tivessem alterado para retirar dele os requisitos só exigidos no direito clássico (assim, o da conveniência; e, do mesmo modo, o do consentimento continuado, cujas faltas acarretariam a dissolução do casamento), não houvessem também eliminado a alusão à captiuitas, que, em seu tempo, não era causa dessa dissolução. Aliás, a não 
retirada da menção à captiuitas foi que levou autores, como Albertario e D'Ercole, a sustentarem o classicismo desse texto. ${ }^{75} \mathrm{E}$ não se pretenda, por outro lado, que ele, ainda que de teor clássico, por haver omitido outras causas de dissolução do matrimônio, como o incesto superveniente (D. $23,2,67,3$ ) e a deportação, poderia igualmente ter silenciado a perda da affectio em virtude de novo casamento, pois esta hipótese, evidentemente, ao contrário das acima aludidas, não só deveria ser mais frequiente do que ambas, mas dizia respeito a elemento inerente ao matrimônio. Em matéria de posse, os juristas romanos não deixam de tratar dos requisitos dela, quer no tocante ao seu inícío, quer no concernente ao seu término.

Em contrapartida, há textos jurídicos e extrajurídicos que se opøem à tese de que o casamento posterior dissolve o anterior independentemente de divórcio ou de repúdio.

Gaio, nas Institutas I, 63, tratando das pessoas que não podem casar umas com as outras, sob pena de contraírem nefarias incestas nuptias, assim alude à ilegitimidade do casamento (uxorem ducere non licet) com sogra ou nora, bem como com enteada ou madrasta:

"Item eam quae mihi quondam socrus aut nurus aut priuigna aut nouerca fuit. Ideo autem diximus 'quondam', quia si adhuc constant esse nuptiae, per quas talis adfinitas quaesita est, alia ratione mihi nupta esse non potest, quia neque eadem duobus nupta esse potest, neque idem duas uxores habere"

E, imediatamente depois, referindo-se inequivocamente a todas essas hipóteses em que faltava conubium entre as pessoas, dava a conseqüência jurídica se, apesar disso, se unissem: não surgia casamento legítimo ("Ergo si quis nefarias atque incestas nuptias contraxerit, neque uxorem habere uidetur neque liberos").

Essa passagem está inserida em contextos das Institutas no qual Gaio trata da falta de conubium entre determinadas pessoas ("Non tamen omnes nobis uxores ducere licet: nam a quarundam nuptiis abstinere debemus"). A afinidade na linha reta existente entre sogro e nora, ou sogra e genro, ou padastro e enteada, ou madastra e enteado, impedia a constituição de casamento legítimo entre esses afins depois de dissolvido o matrimônio em decorrência do qual surgia esse parentesco.

75. Cf. Orestano, ob. cit., p. 86, nota 234. 
Por isso, refere-se Gaio ao elemento temporal quondam, que implica hiato entre a dissolução do matrimônio anterior e o momento em que se pretenderia a constituição de casamento legítimo entre essas pessoas. Nesse caso, o fato impeditivo dessa nova união legítima seria apenas a existência, outrora, da afinidade que decorrera do casamento anterior já dissolvido. Colocou-se, porém, diante de Gaio o mesmo problema com uma diferença temporal: a de o matrimônio entre um dos afins não estar dissolvido, e apesar disso pretender ele unir-se legitimamente ao outro. $\grave{A}$ hipótese do quondam se contrapunha a do si adhuc constant eae nuptiae. Essa questão se apresentaria a Gaio, exigindo dele a distinção que fez, se o segundo casamento necessariamente dissolvesse o primeiro? É claro que não, pois, ainda nesse caso, o fato impeditivo do segundo matrimônio seria a preexistência da afinidade. ${ }^{76}$ Ela, no entanto, se colocaria - como se colocou - diante de Gaio, se o segundo casamento não dissolvesse o primeiro, pois, nesse caso, só haveria esta alternativa: ou ambos os matrimônios coexistiriam, ou a existência do primeiro impediria o surgimento do segundo. O problema se deslocava, portanto, para um fator impeditivo oponível a quaisquer pessoas, independentemente de se examinar a posição de cada uma delas em face do parentesco entre ambas: o princípio monogâmico, que impede que, existente um casamento, se contraía outro, coexistindo ambos. Donde a conclusão rigorosamente lógica de que, enquanto não fosse dissolvido o primeiro casamento, não se poderia contrair o segundo.

Para fugir dessa conclusão e salvar a tese do consentimento continuado, seria necessário imaginar que Gaio, com a frase "si adhuc constant eae nuptiae, per quas talis adfinitas quaesita est", pressuporia a hipótese de o genro querer continuar casado com a filha de sua sogra e ter a esta também como esposa do segundo casamento, pois, assim, persistindo o consentimento para a manutenção do primeiro, o segundo não o dissolveria, mas, ou com ele coexistiria, ou por ele seria impedido de surgir. Sucede, porém, que Gaio não estava tratando da possibilidade, ou não, da coexistência de dois casamentos, para, genericamente, esclarecer que o segundo não poderia constituir-se por causa do princípio monogâmico, mas examinando especificamente a afinidade como fator impeditivo de novo matrimônio, sem qualquer consideração de possibilidade, ou não, de coexistência entre o anterior

76. É o que resulta da parte que não é tida como interpolada do D. XII, 7, 5, pr., e que vem explicitada no $\S 1^{\circ}$, que, como pretende Beseler (Beiträge zur Kritik der romischen Rechtsquellen, vol. III, p. 86, J. C. B. Mohr (Paul Siebeck), Tubigen, 1913), parece ser paráfrase do início do fragmento. 
e o posterior, o que, evidentemente, não pode permitir que da expressão "si adhuc constant eae nuptiae" se extraia o sentido de que ela traduz a intenção de se manter o primeiro casamento e se contrair o segundo, para que ambos coexistam. Aliás, seria absolutamente ilógico que Gaio distinguisse, com base num elemento temporal (quiondam), hipóteses que, entre si, diferiam sob ângulo diverso: o da dissolução já ocorrida do primeiro matrimônio em contraposição à intenção de coexistência de dois matrimônios contraídos em épocas diversas. E mais: seria inconcebível que Gaio deslocasse o problema para esse enfoque diverso e deixasse, em suspenso, a hipótese que seria comum da dissolução do primeiro casamento pelo segundo, hipótese essa que, por ser de dissolução instantânea, pressupõe que "adhuc constant eae nuptiae, per quas talis adfinitas quaesita est", e não que a afinidade tenha resultado de matrimônio já dissolvido outrora (quodam), até porque a verificação da ocorrência do fator impeditivo do segundo casamento necessariamente the precede, e, sem que este surgisse, o anterior, pela concepção do consentimento continuado, não se dissolveria.

Juliano (D. 3, 2, 1) nos dá a conhecer uma passagem do Edito do Pretor, a qual ele assim transcreve, na parte que nos interessa:

"Infamia notatur ... quiue suo nomine non iussu eius in cuius potestate essent, eiusue nomine quem quamve in potestate haberet bina sponsalia binassue nuptias in eodem tempore constitutas habuerit"

Essa referência não pode ser tida como interpolada porque é atestada em constituição de Diocleciano que se encontra no título De incestis et inutilibus nuptiis do Código (C. V, 5, 2), na qual se lê:

"Neminem, qui sub dicione sit Romani nominis, binas uxores habere posse uuglo patet, cum et in edicto praetoris huiusmodi uiri infama notati sint"

Vários autores têm observado que a simples menção, no Edito, à pena de infâmia cominada ao que se apresenta na situação ali descrita (binas nuptias constitutas) demonstra que a celebração de um casamento, ipso facto, não dissolve o anterior. Sollazi, a propósito, assim se exprime: "A intenção de divorciar - o animus perpetuam constituendi dissensionem do $D .24,2,3$, sobre o qual se confira Pringsheim, ZSS, 42 (1922), 283 - não podia manifestar-se com a só passagem a 
novas núpcias, sem uma precedente declaração (vide, todavia, Cic. de orat. I, 40, 183; 56, 238), porque, de outro modo, não se verificaria jamais o caso contido no Edito (D. 3, 2, 1; cf. C 5, 5, 2; 9, 9, 18) das binae nuptiae eodem tempore constitutas". ${ }^{77}$ E Perozzi salienta: "A informação recordada a p. 322, $n$. 3, de Cícero De Orat. 1, 40, 56, em que certos juristas veriam expressa a vontade de divorciar no contrair um novo matrimônio contrasta com a infâmia infringida a quem contrai outras núpcias, perdurando o casamento anterior ${ }^{17}{ }^{78}$

A objeção de que, se o segundo casamento dissolvesse o primeiro, a hipótese do Edito jamais se verificaria (à semelhança, aliás, do que demonstramos com o texto de Gaio em que, se isso ocorresse, não havia razão para distinguir a afinidade passada da afinidade presente, por ocasião do novo matrimônio), é, em si mesma, incontornável. Para fugir dela, Volterra, já em antigo escrito seu (Per la storia del reato di bigamia), ${ }^{79}$ foi obrigado a supor que o que o Pretor pretendia com a imposição da infâmia era punir a má-fé do que, dolosamente, desrespeitasse o princípio monogâmico, fazendo surgir uniões matrimoniais de fato que deixariam em dúvida a sociedade quanto à exata posição jurídica do mesmo. Eis as palavras que, a propósito, então escreveu:

"Se nós, porém, lermos atentamente o texto do Edito e os comentários relativos conservados no título $D$. de his qui notantur infamia 3, 2, veremos como o Pretor não se baseava na existência jurídica de dois matrimônios contemporâneos, mas exclusivamente perseguia o fato de constituir ou de procurar constituir ao mesmo tempo duas uniões estáveis, contínuas, ainda que se tratasse de uniões que juridicamente não podiam ser consideradas iustae nuptiae. A infâmia pune aqueles que desrespeitam o princípio monogâmico, fazendo surgir mais uniões matrimoniais de fato (na verdade não sendo juridicamente tais), de modo que deixassem em dúvida a sociedade de sua exata posição jurídica e de

77. Studi sul Divorzio, in Scritti di Diritto Romano, III, p. 37, nota 11, Casa Editrice Dott. Eugenio Jovene, Napoli, 1960.

78. Ob. cit., v. I, p. 367 , nota 2.

79. In Studi in Memoria di Umberto Ratti, p. 389-447. 
modo que a trouxesse dolosamente em engano. Compreende-se que ainda neste campo o que se quer perseguir é sobretudo a má-fé e compreende-se ainda como a cominação da infâmia não impede que o mesmo ato possa por vezes cair sob a figura do adultério ou do incesto". 80

Sucede, porém, que a suposição de Volterra, além de não encontrar elementos de apoio no texto do Edito nem nos comentários que lhe fez Ulpiano (D. 3, 2, 13, 1 a 4), entra em choque com eles. Com efeito, observa Ulpiano (D. 3, 2, 13, 3) que também é castigada com a pena da infâmia a mulher que, após haver contraído esponsais com um, se casou com outro, hipótese em que, evidentemente, não há que se falar em má-fé para ludibriar a sociedade sobre a posição jurídica dessa mulher. Mas, não é só. O mesmo Ulpiano (D. 3, 2, 13, 4) declara que, segundo o Edito, como o que se censura é o fato em si mesmo, também incorre na infâmia o que contraiu núpcias ou esponsais com mulher com a qual não poderia, ou não seria lícito, casar-se, o que implica dizer que não se levava em consideração elemento subjetivo (má-fé); ademais, a alusão a essa hipótese de o segundo casamento ser ilegítimo em decorrência de proibição de que resultasse a ausência de conubium entre os contraentes só se explica como esclarecimento de que nela também ocorria o que se verificava normalmente quando não houvesse, para impedir a constituição do segundo matrimônio, outro fator obstante que não a violação do princípio monogâmico.

Aliás, é de observar-se que, na hipótese das binae nuptiae, constituição de Valeriano e Gảilieno, do ano 258 d. C., que está reproduzida, em partes diversas, em dois textos do Código $(5,3,5$; e 9, 9, 18), demonstra, no último desses fragmentos, que o segundo casamento é nulo pelo fato de não ser possível contrair vários matrimônios concorrentemente. Com efeito, esse texto declara que o homem que teve duas esposas é punido com a infâmia, e, como o que então se pune é a intenção e não o fato de ser proibido contrair vários casamentos, se a segunda mulher estiver de boa-fé por haver o homem, que continuava casado na província, simulado o celibato, a acusação de stuprum só se fará contra ele e não contra ela que julgava ser esposa legítima. Embora haja interpolações nesse texto, elas não o 
atingem na parte de que decorre que o segundo casamento é nulo apenas pela proibição de se contraírem vários matrimônios (princípio monogâmico), tanto assim que ele declara que a pena de infâmia se comina, não pela circunstância objetiva dessa proibição, mas pela má-fé: "... in ea (infamia) namque re non iuris effectus, quo ciues nostri matrimonia contrahere plura prohibentur, sed animi destinatio cogitur" À observação de Robleda de que esse texto demonstra que o segundo casamento não dissolve o primeiro, responde Volterra que, no caso, essa dissolução não ocorre somente porque o homem e a primeira mulher queriam preservar $o$ matrimônio deles, o que impedia àquele que desse seu consentimento para contrair o segundo casamento, que, não surgindo por falta do indispensável consensus, não dissolvia o casamento anterior. Ocorre, porém, que Rasi ${ }^{81}$ já observava que o texto alude, para caracterizar a má-fé do homem, a ficto caelibatu e não a ficta affectione, donde, com base nele, não se poder pretender que o segundo matrimônio inexistiria por falta do consentimento inicial. A ilegitimidade dele decorria tão-só da existência do anterior (ficto caelibatu), que, ao invés de ser dissolvido por ele, lhe impedia a constituição.

Esses textos jurídicos - deixam-se de lado outros em que a alegação da existência de interpolações, ainda que muitas vezes altamente discutíveis, pode tornar duvidosa sua valia para o Direito Romano clássico - mostram que, no período clássico, a existência do primeiro casamento impedia o segundo, não sendo este, portanto, causa da dissolução necessária daquele pela cessação do requisito do consentimento contínuo, ou modo de substituição do divórcio.

Há, porém, dois textos de Cícero (De Orate, I, 40, 183; e I, 56, 238) que demonstram que, em época anterior à dele (quod usu memoria patrum uenit), havia dúvida sobre se, para a dissolução do primeiro casamento, era necessário divórcio formal ou se a constituição do segundo casamento o supriria. Narra ele que um homem, deixando sua mulher grávida, partiu da Espanha para Roma; ali tornou a casar, sem divorciar-se formalmente da primeira esposa (neque nuntium priori remisisset). Teve ele filho de uma e de outra mulher e, ao morrer ab intestato, surgiu a questão de saber qual o status da segunda consorte e de seu filho, para que se decidisse sobre a herança. Como não houvera divórcio formal, se se julgasse insuficiente o novo matrimônio para dissolver o anterior, a segunda esposa seria considerada concubina ("si iudicaretur certis quibusdam uerbis, non nouis nuptii

81. Ob. cit., p. 199-200. 
fieri cum superiore diuortium, in concubinae loco duceretur"). E o próprio Cícero informa, mais adiante (I, 56, 238), que essa causa (note-se que ele não diz que se tratava de questão em aberto) a relativa à criança nascida de uma segunda esposa sem que a primeira tivesse sido formalmente repudiada - deu margem a grande controvérsia entre os mais notáveis jurisconsultos. Ainda que Cícero não tenha notificado qual a opinião que prevaleceu e que seria a observada em seu tempo, o que é certo é que a forma por que é colocada a discussão nesses textos é incompatível com a concepção do consentimento contínuo. Com efeito, como salienta Cícero, o que se discutiu, para se saber qual o status da mulher do segundo casamento e de seu filho, foi se o segundo matrimônio só seria válido se o primeiro tivesse sido desconstituído por divórcio formal (nuntium priori remisisset; certis quibusdam uerbis) ou se aquele implicaria divórcio tácito. Portanto, a dissolução do primeiro casamento pelo segundo, na alternativa da discussão, decorreria de esse ser tido como forma de manifestação tácita de divórcio, e não de, por ele, cessar, para o primeiro, o requisito do consentimento contínuo. $\mathrm{O}$ segundo casamento, por traduzir inequívoca vontade de desconstituir o primeiro, seria, pois, o ato contrário que dissolveria este. Aliás, se o consentimento continuado fosse da essência mesma do casamento romano o que, evidentemente, seria sabido de todos -, não poderia haver dúvida alguma de que o segundo casamento teria dissolvido o primeiro, por implicar a cessação, quanto a este, do consentimento contínuo de que dependia sua permanência. Se houve séria controvérsia entre peritíssimos jurisconsultos é porque, evidentemente, essa concepção não existia e o problema se punha, no caso concreto, em outros termos: o segundo casamento poderia ser considerado manifestação tácita de repúdio? E essa colocação está a demonstrar que o repúdio expresso ou tácito era necessário, o que afasta a dissolução do casamento por simples cessação do consentimento continuado, uma vez que se exige, para o término dele, ato inequivocamente contrário ao consentimento que lhe deu origem.

Se o texto de Cícero é incompatível com a concepção do consentimento continuado, deixa ele, no entanto, sem solução a questão de saber se o primeiro casamento impedia o segundo, pois este poderia ser entendido como traduzindo manifestação tácita de repúdio.

É do período que vai da segunda metade do século I d. C. à primeira metade da centúria seguinte ${ }^{82}$ o texto extrajurídico que afirma que o casamento posterior não dissolve o anterior, o que implica dizer que este impede que aquele 
surja validamente. Trata-se de uma das declamationes minores a de n. 347 - cuja atribuição a Quintiliano é controvertida.

A declamatio 347 versa a hipótese de mulher que, julgando rumoribus que o marido ausente estava morto, se casa de novo; mas o primeiro esposo retorna à casa, e a encontrando no leito com o segundo marido, a mata como adúltera. Nessa declamatio, lêm-se estas palavras iniciais:

"Adulteros fuisse in matrimonio constat; nemo negat. Matrimonium duobus generibus soluitur, aut repudio, aut morte alterius: neque repudiaui, et certo uiuo: sed rumor de morte ueni; haec statim nupsit, alio marito: quid est hoc aliud, quam improbius adulterium? Meae igitur nuptiae manserunt, illae non fuere legitimae: legitimum porro matrimonium, nisi soluto priore, esse non potest: an opinione contenti sumus?"

A clareza do texto é absoluta no sentido de que o segundo casamento não dissolve o primeiro. A mulher, ainda que levianamente contentou-se ela com o boato da morte do marido -, julgou-se viúva e contraiu novo casamento. A existência do consensus para as novas núpcias é indiscutível, pois o próprio marido assassino, em sua defesa, admite que sua mulher e o segundo esposo estavam de boa-fé: adulteri fuerunt, etiamsi ignorauerunt. Apesar disso, afirma ele que, por persistir seu casamento, o segundo era ilegítimo, uma vez que não ocorrera qualquer dos modos pelos quais o matrimônio se dissolve. A alusão apenas ao repúdio e à morte como causas de dissolução do casamento se explica por serem elas, não só as mais comuns, mas as únicas que poderiam ter ocorrido no caso. Se o consentimento contínuo fosse essencial à persistência do primeiro matrimônio, e, portanto, tivesse ele deixado de existir com a celebração do segundo, seriam inexplicáveis as afirmações de que meae igitur nuptiae manserunt, illae non fuere legitimae: legitimum porro matrimonium, nisi soluto priore, esse non potest. Por elas, é inequívoco que o casamento para dissolver-se por ato de vontade demanda a ocorrência do divórcio como ato contrário ao que lhe dera início, não podendo fazer as suas vezes um novo matrimônio, a título de divórcio tácito. A objeção que se retira dessa declamatio é tão séria que Volterra, ao responder, em 1975, às dúvidas de Robleda (que, a propósito, apenas citara, em nota, algumas de suas frases, sem 
tecer considerações), ${ }^{83}$ escreveu quatro páginas com o objetivo de retirar-lhe a contundência. Em última análise, procurou Volterra demonstrar que as afirmações iniciais dessa declamatio eram apenas algumas frases isoladas postas na boca do imputado pelo retor, não se thes podendo atribuir o valor de normas jurídicas ou de princípios, pois a base da defesa do primeiro marido foi demonstrar seu erro de fato (não sabia do novo casamento e as circunstâncias o levaram a considerar que sua esposa cometia flagrante adultério quando ele retornou), e, por isso, o exercício retórico visa não tanto a sustentar a condição objetiva da mulher ainda juridicamente esposa do assassino, mas a evidenciar a persuasão deste da persistência do primeiro casamento e, portanto, a certeza subjetiva de agir contra uma adúltera. A fragilidade da resposta é manifesta. Não cuidou Volterra de pretender invalidar o texto sob a alegação de que as afirmações nele contidas sobre o casamento e o divórcio eram tiradas do direito grego ou resultavam do delírio imaginativo dos retores. Paoli, no artigo Droit Attique et Droit Romain dans les Rhéteurs Latins, ${ }^{84}$ estudando o desenvolvimento histórico dos temas e das argumentações nas escolas dos retores latinos, demonstra que, à medida que o tempo foi passando, surgiram temas novos, extraídos da vida e do direito romanos. Eles acentua Paoli - "se distinguem pelo seu caráter mais sério e pelo fato de que o problema colocado pelo tema retórico é encarado como um verdadeiro problema jurídico" ${ }^{85}$ É o que sucede quanto à declamatio em causa. O tema é jurídico e é romano, como resulta inequivocamente de fragmento de Papiniano, tirado do livro de adulteriis (D. 48, 5, 12, 12), o qual, apesar das interpolações que nele têm sido apontadas, é nessa parte de genuidade dificilmente atacável (aliás, a hipótese nele figurada, por si mesma, demonstra que a inequívoca perda da affectio pela mulher tanto que não esperou a confirmação do boato para casar-se de novo - não dissolvia o primeiro casamento, razão por que era discutível se ela poderia ser punida, por adultério): mulier cum absentem uirum audisset uita functum esse, alli se iunxit: mox maritus reuersus est. Quaero, quid aduersus eam mulierem statuendum sit. E seu tratamento, na declamatio, é jurídico, porquanto voltado à defesa da licitude do ato do primeiro marido que matara a mulher e o homem com quem ela havia celebrado o segundo matrimônio. Essa defesa se divide em duas partes. Na primeira - que, como sucede nas declamationes,

83. P. $260-3$.

84. In Revue Hustorique de Droit Français et Étranger, quarta série (31ªno), 1963, p. 175-199.

85. P. 176. 
leva em conta o direito anterior à Lex lulia de adulteriis (Aulo Gelio, Noctes Atticae, $X, 23,5)$-, sustenta o réu que lhe era lícito matar pelo só fato de que, mantendo-se o seu casamento, a mulher, contraindo outro, se tornara adúltera. Já na segunda, seguese a técnica do procedimento retórico, que consiste em passar do plano objetivo extra-individual para o de considerações subjetivas individuais (no terreno penal, a intencionalidade do acusado). ${ }^{86}$ Partindo da admissão da boa-fé de sua mulher e do segundo esposo, bem como da influência que essa circunstância poderá exercer sobre o ânimo dos juízes (possitis occisorum fortasse misereri, quod decepti sunt, quod illos spes sua fefellit), procura o primeiro marido demonstrar que ainda quando ele não soubesse que era lícito ${ }^{87}$ matar os dois adúlteros, seria justificável que os tivesse morto, não só pelas circunstâncias que encontrara em seu retorno, mas também pela leviandade da mulher que não perquirira sobre o boato de sua morte, em razão da qual se tornara sua herdeira e se casara de imediato com um jovem, a quem dera sua casa em dote e que fora a origem do boato que levara ao novo casamento. Essa segunda parte da defesa não visa evidentemente a caracterizar como pretende Volterra a persuasão do primeiro marido da persistência do seu casamento, o que não teria qualquer sentido por ser antagônica à primeira, pela qual a permanência do matrimônio anterior resultava objetivamente da ausência das duas causas que o poderiam ter dissolvido: a morte ou o divórcio. Se a licitude da ação do primeiro marido decorria dessa circunstância objetiva da permanência do seu casamento (daí dizer ele: mihi ad defensionem hoc satis est: licuit), seria totalmente desarrazoado que ele viesse a destruí-la com a alegação de que as circunstâncias o haviam induzido ao erro de pensar que a mulher ainda continuava casada com ele por não saber que ela contraíra novo casamento, o que implicava que este dissolvera o seu. Nada há nela que diga respeito a dúvida sobre o consentimento contínuo (affectio) da mulher, o que, como já salientado, destruiria a alegação inicial, que, ademais, seria inconcebível, se contrária à concepção correntia que os romanos, nessa época, tinham do matrimônio.

86. A propósito, vide Lanfranchi, ob. cit., p. 65-6.

87. É o que resulta da frase "An ego si ignorassem quod diceret, non occidissent?" (ed. Ritter, p. 367), com a correção feita por Petrus Aerodius (M. F Quintiliani Declamationes CXXXVII, 184 verso, Apud Fredericum Morellum, Paris, 1563), que ai lê liceret em vez de diceret, o que se compatibiliza com o contexto. Essa correção, como acentua Ritter (p. 367, nota), foi acolhida por outros editores (alii). 
Aliás, o próprio Volterra, em artigo que, muitos anos antes de sua resposta às dúvidas de Robleda, publicou nos Studi in Onore di Vicenzo ArangioRui $^{88}$ sobre uma misteriosa lei atribuída a Valentiniano I pelo escritor cristão Sócrates, o Escolástico, e que teria permitido ao homem ter, ao mesmo tempo, várias mulheres, diz que a narração desse autor se choca com a concepção clássica do casamento romano, que, com base no princípio monogâmico, levava à conseqüência de que o segundo matrimônio dissolvia o primeiro, por ser prova da cessação da vontade contínua de permanecer casado. E, depois de examinar as passagens de outros autores antigos a esse respeito, acentua ${ }^{89}$ que os argumentos em favor dessa pretensa lei e contra ela o deixavam perplexo, sem poder chegar a uma conclusão sobre o mistério desse mérito histórico, embora tais textos tivessem a virtude de fornecer um dado importante para a história da estrutura jurídica do casamento romano: na segunda metade do século IV d. C., as iustae nuptiae não mais se fundavam no consentimento continuado, e, sim, no consentimento inicial, constituindo um negócio jurídico. Para assim concluir, salienta:

"Prova disso era que se podia imaginar o episódio, verdadeiro ou falso que fosse, de uma lei que permitisse a um homem, já unido em casamento legítimo, manifestar, nas devidas formas, a vontade juridicamente válida de formar um segundo matrimônio com outra mulher, sem com isso dissolver ipso iure o primeiro vínculo conjugal. Norma essa que nenhum jurisconsulto clássico teria podido conceber ${ }^{\prime \prime 0}$

Ora, com o propósito, os textos examinados por Volterra são extrajurídicos, daí resulta que, sendo o casamento romano um fato precipuamente social, não seriam só os juristas que não poderiam conceber que o segundo casamento não dissolvesse o primeiro, mas também os autores literários. Para quem como Volterra faz essa afirmação, cuja lógica é perfeita, não é contraditório que não dê maior valor ao texto claríssimo da declamatio atribuído a Quintiliano, no qual se

88. Una misteriosa legge attribuita a Valentiniano I, in Studi cit., vol. III, p. 139-154, Editore Jovene, Napoli, sem data.

89. Ob. cit., p. 153 .

90. Ob. cit., p. 153 
pð̃e como tese (e não como frase solta) que legitimum porro matrimonium, nisi soluto priore, esse non potest?

Mas, a mesma razão que conduziu Volterra a concluir que a simples notícia de uma duvidosa lei que admitia a possibilidade da coexistência de vários casamentos demonstrava que, na segunda metade do século IV d. C., já não mais vigorava a concepção do consentimento continuado leva a concluir que essa concepção não existia no direito clássico até o tempo de Aulo Gélio.

De feito, refere Suetônio ${ }^{91}$ que o tribuno da plebe Hélio Cina disse a várias pessoas que Júlio César lhe havia confiado, para ser proposto ao povo em sua ausência, o texto de uma lei, pela qual lhe seria permitido esposar quantas mulheres desejasse, para assegurar sua descendência. Esse fato - não importa se verdadeiro ou falso atesta, indubitavelmente, que nos fins da república era perfeitamente concebível a concomitância de casamentos, desde que admitida por lei. O escrúpulo do conquistador da Gália quanto à ocasião da propositura era justificável pelo privilégio que pretendia. Se o casamento romano fosse um estado de fato que dependesse do consentimento contínuo, a pretensão de César seria demasiado revolucionária para que Suetônio se limitasse a seco registro.

Ainda mais expressivo, nessa mesma linha de raciocínio, é o episódio narrado por Aulo Gélio ${ }^{92}$ sobre a origem do sobrenome Praetextatus, e que foi extraído de uma das orações de M. Cato (Ad milites contra Galbam). Conta-se que Papírio, que, segundo a tradição antiga, frequientava o Senado levado pelo pai, ao ser indagado por sua mãe sobre o que em certa sessão se decidira, mentiu, para guardar segredo, dizendo que se debatera sobre se seria mais conveniente à república um homem poder casar com duas mulheres, ou uma mulher com dois homens. Sabedora disso, sua genitora reuniu outras matronas, e foram ao Senado no dia seguinte, suplicando que se decidisse que uma mulher pudesse casar-se com dois homens, e não que um deles pudesse ter duas esposas. Esclarecida, pelo menino Papírio, a razão de ser daquela súplica, deliberaram os senadores não mais levar, a partir de então, seus filhos às sessões do Senado, fazendo-se exceção àquele, que foi cognominado Praetextatus por causa de sua prudência, apesar de achar-se in aetate praetextata. Esse episódio revela que, em pleno período clássico, podia imaginar-se que uma deliberação do Senado permitisse a coexistência de dois casamentos, sem

91. Diuus Iulius, 52.

92. Noctes Atticae, I, 23 (vide, também, Macróbio, Saturnales, 19-26). 
maior comoção social, tanto assim que, segundo a tradição, as matronas romanas não tiveram dúvida em acreditar nas palavras do menino, e só se preocuparam em que seus maridos não tivessem duas esposas, pretendendo, sim, o contrário. E Aulo Gélio não demonstra qualquer perplexidade pelo que, nesse fato, seria insólito em face da concepção do casamento que a sociedade romana teria.

Totalmente diversa é a atitude de Tácito com relação à união de Messalina com C. Sílio, narrada nos Anais. ${ }^{93}$

Já Piero Rasi se valia desse episódio como argumento contrário à tese do consentimento continuado, fazendo estas observações:

"Um outro caso para recordar-se é aquele descrito por Tácito quando fala das relações entre Messalina e Cláudio. Ele narra como Messalina facilitate adulteriorum in fastidium uersa, ad incongnitas libidines profluebat, em um certo momento sem enviar o repudium a Cláudio, sem observar as formalidades prescritas, celebra reais núpcias com um certo Silius. $O$ matrimônio que daí resulta é nulo, ou melhor, inexistente, não obstante ela tivesse palam manifestado sua vontade de divorciar-se contraindo novas núpcias sollemniter et coram populo et senato. E efetivamente Cláudio tomando disso conhecimento a pune como adúltera. $O$ historiador mesmo considera adulterina a segunda união; interessante é ver como ele nos fala do fato. Depois de haver descrito o episódio, ele, que jamais se havia maravilhado, frio historiador, sente a necessidade de defender-se da pecha do simplório: haud sum ignarum fabulosum uisum iri no contar o fato como tendo ocorrido com grande solenidade, publicamente, com a intervenção das autoridades religiosas, sendo, ainda, a relação consumada palam: oscula complexus, noctem denique actam licentia coniugali. Pede excusa disso: sed nihil compositum miraculi causa, uerum audita scriptaque senioribus trado. 
Se fossem fundadas as conclusões a que chegaram os nossos romanistas especialmente Bonfante, não haveria razão para que Tácito se desculpasse tanto. As segundas núpcias de Messalina eram legítimas e não certamente fabulosae!". ${ }^{94}$

Volterra, no rude e minucioso ataque que fez ao livro de Rasi, ${ }^{95}$ não disse uma palavra sobre essas observações, que, sem dúvida, a quem esteja de espírito desarmado, impressionam. Apesar de seu notável conhecimento das fontes jurídicas e extrajurídicas e esse episódio narrado por Tácito é demasiadamente conhecido -, não rebateu a objeção, nem tampouco se valeu do texto do historiador romano para demonstrar que ele, ao contrário, seria a prova, em fonte literária, da veracidade da tese de que o segundo casamento dissolvia ipso iure o primeiro, como conseqüência da necessidade do consentimento contínuo. Somente em 1975, quase trinta anos depois, é que, na resposta às dúvidas de Robleda, examina esse episódio para o qual Bickerman, em carta privada, the chamara a atenção depois de ler um escrito de Guarino (In difesa di Messalina) e conclui, valendo-se também das narrações de Suetônio e de Dion Cássio, que ele "fornece uma prova ulterior à tese por mim sempre sustentada" ${ }^{96}$

O simples fato de ter sido necessário tanto tempo para que um romanista do porte de Volterra viesse a perceber que o texto de Tácito que sempre despertou perplexidades, não sendo, portanto, uma passagem de menor expressão serviria de confirmação para a sua tese (e confirmação que, no dizer de Bickerman, era éclatante $)^{97}$ evidencia que, para se chegar a essa conclusão, há extremas dificuldades.

Com efeito, como observou Rasi, se o casamento posterior dissolvesse o anterior, não haveria motivo para que Tácito dissesse que o episódio que sob esse aspecto seria normalíssimo - parecia fabuloso e se escusasse com a ressalva de que nihil compositum miraculi causa, uerum audita scriptaque senioribus tradam. ${ }^{98} \mathrm{E}-$

94. Ob. cit., p. 136-7.

95. Recensio cit.

96. Precizazioni in tema di matrimonio classico, in ob. cit., p. 269

97. Idem, p. 264.

98. Annales, XI, 27. 
note-se - o que se lhe afigurava digno de fábula era o fato mesmo do casamento com Sílio:

"Estou certo de que há de parecer incrivel ter podido, com tanta segurança, numa cidade onde tudo se sabe e se comenta, já não digo um cidadão qualquer, mas próprio cônsul designado, unir-se à esposa do príncipe, em dia marcado, presentes as testemunhas, como para legítimas núpcias, e que ela tenha ouvido as palavras dos augures, sacrificado aos deuses, tomado parte do banquete nupcial, entre beijos e abraços $e$ passasse a noite com a liberdade conjugal. Ao narrar esses fatos, nada invento ou encareço, exponho apenas o que li e o que ouvi dos mais velhos" 99

Imediatamente antes dessa passagem dissera Tácito que "Messalina enfastiada da facilidade de seus adultérios se arrojava a desconhecidos excessos"; que Sílio é que a impelia a que rompessem com a dissimulação e que resolvessem não esperar pela velhice do príncipe, porque se as resoluções moderadas convêm aos inocentes, aos crimes manifestos só pode remediar a audácia; e que Messalina ouvia com frieza estas propostas, não por amor ao marido, mas receosa de que Sílio, tendo alcançado o poder, viesse a desprezar a adúltera e depois estimasse em seu verdadeiro preço um crime justificado por força do perigo. Afinal decidiu-se ao casamento por causa da magnitude da infâmia, último prazer para os que abusaram de todos os outros.

Essas palavras são inequívocas no sentido de que o casamento com Sílio seria çriminoso: o adultério às escâncaras. Se o segundo matrimônio fosse meio normal de dissolver o primeiro, não teria sentido que Tácito dissesse que Messalina, cansada da facilidade de seus adultérios, ad incognitas libidines profluebat; que Sílio, depois de alcançar o. poder, a viesse desprezar como adúltera, se, após justificado o crime no tempo de perigo, o estimasse em seu verdadeiro preço; que Messalina, pela magnitude da infâmia, nomem matrimonii concupiuit; e que era inacreditável que um cônsul designado, em dia marcado, cumprisse com Messalina

99. Annales, XI, 28 (tradução de Leopoldo Pereira, Anais de C. Cornélio Tácito, p. 244-5, Imprensa Nacional, Rio de Janeiro, 1964). 
todas as cerimônias sociais e religiosas, como em um casamento destinado à legitimidade dos filhos.

A narração de Tácito dos fatos posteriores a esse casamento com Sílio prossegue na linha de consideração do crime de adultério que ele configurava. $\mathrm{O}$ horror que se apoderou dos que cercavam Cláudio era decorrente, este sim, do medo de ele vir a ser destronado, perdendo aqueles o poder. Mas teria sentido que Tácito dissesse, após o segundo casamento, que a fraqueza mesma do imperador lhes inspirava a esperança de, se o convencessem da Enormidade do Crime, poder ser ela condenada antes de acusada, e que Narciso encarregou da denúncia duas meretrizes da intimidade dele, fazendo-lhes larguezas e promessa de que maior se tornaria a influência delas depois que ele tivesse rejeitado a esposa (uxore deiecta)? Se Messalina deixara de ser sua mulher, seria possível que Cláudio a rejeitasse como se ela continuasse a sê-lo? Como poderia Narciso, logo depois da notícia dos fatos dada a Cláudio pelas meretrizes, dizer-lhe que não importava que Sílio ficasse de posse da casa, dos servos e de toda a magnificência imperial; que de tudo gozasse, mas que restituísse a mulher e rasgasse a ata do casamento? $\mathrm{O}$ rasgar a ata do casamento faria Messalina retornar, automaticamente, à condição de esposa de Cláudio, se o segundo matrimônio fosse válido? E as frases que se seguem, e que aparentemente dariam a entender que o segundo casamento significaria repúdio, e, portanto, dissolução do primeiro, em verdade, demonstram o contrário nesse contexto. Se o segundo casamento dissolvesse o primeiro, Cláudio, que já tivera conhecimento do fato pelas meretrizes, evidentemente saberia disso, e não teria razão de ser a pergunta que Narciso lhe fez: Não sabes, então, que estás repudiado? E, em seguida, a título de explicação, acrescentasse: Porque o povo, o Senado e os soldados viram o matrimônio de Sílio (nam matrimonium Silii uidit populus et senatus et miles). Pergunta e explicação que se justificam, sim, como forma de incitar a ira de Cláudio, tendo em vista a finalidade a que visava Narciso: e, se não te apressas, o marido de tua mulher tomará posse da cidade.

Repudiado Cláudio pelo segundo casamento válido, não justificaria que, prosseguindo, Tácito dissesse que, sabedora do regresso de Cláudio a Roma, Messalina decidira ir ao encontro do marido (ire obviam et aspici a marito), se Cláudio não mais o fosse; que informasse que, entre as palavras contraditórias do imperador, este condenava os crimes da mulher (flagitia uxoris), e que, quando se recordava de seu casamento com ela e da infâmia de seus filhos, Vitélio nada mais fazia que exclamar: Que horror! Que crime! 
Essas circunstâncias indicam que o casamento de Cláudio com Messalina persistiu apesar de sua união com Sílio, cumpridas todas as formalidades sociais e religiosas que normalmente se faziam para caracterizar a celebração de iustae nuptiae. Por isso mesmo resulta da narração de Tácito que ambos cometeram o crime de adultério, o que seria inadmissível, se o segundo casamento houvesse dissolvido o primeiro.

O mesmo, aliás, decorre de uma alusão a Messalina que se encontra na sátira a Cláudio (Diui Claudi Apocolocyntosis) escrita por Sêneca, que foi contemporâneo do episódio narrado por Tácito, a ele não havendo assistido por estar exilado na ocasião. Morto o príncipe, solicita ele admissão no céu, e, na assembléia dos deuses, determina-se sua expulsão para o inferno, por proposta do divino Augusto, que a fundamenta no fato de, sem processo, haver Cláudio matado inúmeras pessoas, entre as quais alguns parentes afins e sua esposa Messalina (Quandoquidem Diuus Claudius occidit ... uxorem suam Messalinam) (XI, 5). Se a união dela com Sílio (a quem Sêneca, em outra passagem da sátira XIII, 4 -, se refere como cônsul designado) houvesse dissolvido seu casamento com Cláudio, não seria ela esposa deste, ao ser morta.

A configuração desse segundo casamento como crime de adultério não só decorre da narração de Tácito como, ainda - e de modo evidente -, da versão do episódio acolhida por Juvenal. ${ }^{100}$ Ela difere da de Tácito, por atribuir a Sílio a posição de vítima de Messalina, que o colocara no dilema de não concordar com a celebração das núpcias e ser morto por ela que concretizaria suas ameaças de morte, ou com ela concordar e viver mais alguns dias, até que o fato chegasse ao conhecimento de Cláudio e este lavasse a honra de seu lar (ni parere uelis, pereundum erit ante lucernas; si scelus admittas, dabitur mora paruula, dum res nota urbi et populo contingat principis aurem). O si scelus admittas evidencia que essas núpcias eram criminosas e isso, sem dúvida, porque adulterinas. No caso, portanto, não estava em jogo o adultério anterior entre Messalina e Sílio.

Por outro lado, que a união de Messalina com Sílio não era uma matrimonium iustum resulta ainda de outras duas circunstâncias. Diz Tácito que Messalina, instada por Sílio a romper a dissimulação contraindo núpcias com ele, nomem matrimonii concupiuit. Essa expressão é sintomática até pela causa desse desejo ardente: ob magnitudinem infamiae, cuius apud prodigos nouissima uoluptas 
est (por causa magnitude da infâmia, último prazer para os que abusaram de todos os outros). Por que o contrair matrimonium iustum decorreria da vontade de se exceder na infâmia? ${ }^{101}$ Embora a expressão nomen matrimonii possa traduzir a idéia de matrimônio legítimo, como no fragmento atribuído a Ulpiano e que se encontra no D. 23, 3, 3 (Ubicumque igitur matrimonii nomen non est, nec dos est), a palavra nomen, em autores como Cícero, Tito Lívio e Pomponius Mela, é empregada como algo oposto à realidade e, portanto, como simples designação sem o conteúdo correspondente. Assim, a título de exemplo, em Cícero, Epistolae ad Atticum V, 15, 1 (cum exercitum noster amicus habeat tantum, me nomen habere duarum legionum exilium); em Tito Lívio (Ab Urbe condita III, 65: iamque plebs ita in tribunatu ponere aliquid spei, si similes Icilio tribunos haberet: nomina tantum se biennio habuisse; V. 18: me iam non eundem, sed umbram nomeque P. Licinii relictum uidetis; VII, 29: Campani magis nomen ad praesidium sociorum, quam uires, quum attulissent; XXIX, 1: Praeterquam quod nomina tantum ducum in Hispania Romani haberent); e em Pomponius Mela (De Situ Orbis II, 3: Thoricos et Brauronia, olim urbes, iam tantum nomina). E o Imperador Zenão (C. 5, 5, 9), reafirmando a proibição das núpcias incestuosas, tornou sem efeito constituições impias que permitiram a algumas pessoas, em tempo de tirania, aplicar o nome de matrimônio a contubérnio criminoso (quae quibusdam personis tyrannidis tempore permiserunt scelesto contubernio matrimonii nomen imponere). Porque Messalina desejava ardentemente apenas o nomen matrimonii é que e essa é a segunda circunstância que aludimos - suas núpcias se exteriorizaram com todas as formalidades sociais e religiosas usadas nas iustae nuptiae. Se se tratasse de verdadeiras núpcias, Tácito, depois de dar ênfase a que essas núpcias se celebraram com as solenidades habituais, as enumeraria uma a uma como se destinassem a um casamento legítimo (uelut suscipiendorum liberorum causa), e isso para caracterizar o fato incrível de um cônsul designado unir-se publicamente com a esposa do príncipe? Por que a mesma

101. Volterra (Precizazioni in tema di matrimonio classico, p. 265) diz que Tácito insiste em mostrar que a união entre Messalina e Sílio era um casamento legítimo, tanto assim que "Tácito expõe claramente o temor de Messalina que Sílio, uma vez conseguidos os altíssimos cargos a que aspirava, desprezasse a mulher adúltera (tal, de feito, ocorreria se a relação entre eles não tivesse constituido um matrimônio legítimo e permanecesse vivo o casamento entre ela e Cláudio) e que, portanto nomen matrimonii concupiuit ob magnitudinem infamiae" $\mathrm{O}$ texto de Tácito, porém, salienta, ao contrário, que a frieza com que Messalina ouvia as propostas de Sílio (inclusive a de casamento) decorria do receio de que ele, alcançado o poder, viesse a desprezar a adúltera, o que, evidentemente, apenas ocorreria se essas núpcias não dissolvessem o matrimônio dela com Cláudio. E, só então, Tácito acrescenta: "Todavia, desejou ardentemente o nomen matrimonii, por causa da magnitude da infâmia, último prazer para os que abusaram de todos os outros" 
ênfase no enumerar essas solenidades que se encontra em Juvenal, ao dizer que elas se observaram porque Messalina queria unir-se a Sílio, não em segredo como ele desejava, mas com a observância de todas as regras de um iustum matrimonium (non nisi legitime uult nubere)? Mais, Dion Cássio ${ }^{102}$ diz que Messalina, não contente com os adultérios, desejou ter vários maridos, casando-se, por contrato legal, com todos que tivessem seus favores, o que não lhe foi possível por ter sido descoberta e destruída exatamente em sua primeira tentativa. Não está essa informação a indicar que o casamento com Sílio configurava as binae nuptiae proibidas pelo princípio monogâmico?

O espantoso do fato - o adultério às escâncaras da esposa do príncipe com os requintes formais de uma união escandalosa como se fora casamento - não explica a versão que havia em Roma, e que Suetônio ${ }^{103}$ noticia embora a julgasse inverossímil, de que se tratara de uma simulação de casamento, da qual participara Cláudio, para fazer recair em outrem perigo que lhe ameaçava segundo certos presságios?

Recentemente, Núñes Paz, ${ }^{104}$ decidida adepta da concepção do consentimento continuado, examinando a relação entre Messalina e Sílio, entende, com Volterra, que a circunstância, aludida por Tácito, de que Messalina nomen matrimonii concupiuit, não significa que ela não quisesse contrair casamento, mas apenas criar uma aparência. Ao contrário, por desejarem Messalina e Sílio realmente celebrar iustae nuptiae, deixou de existir a effectio que mantinha o matrimônio dela com Cláudio, razão por que, com a celebração das novas núpcias, se divorciou do primeiro marido, sem que, no entanto, sua união com Sílio constituísse contrariamente ao que sustenta Volterra iustum matrimonium, pois entre eles faltava o conubium, dada a existência da anterior relação adulterina, obstáculo às iustae nuptiae introduzido pela legislação de Augusto.

Essa tese - que tem o casamento de Sílio com Messalina como iniustum matrimonium, mas, não obstante isso, com a eficácia de dissolver o iustum

102. História Romana, LXI, 31, 1 e 2.

103. Diuus Claudius, XXIX. Essa versão é reproduzida pelo antigo escoliasta de Juvenal em comentários ao verso 330 da Sátira X (p. 315 da edição Firmin Didot, v. Il das Decimi lunii luuenalis Satirae, Paris, 1810. Aurélio Vitor (Historiae Abreuiatae, 4, 11), no século IV, a ela se refere, dizendo apenas, quanto à uniåo de Messalina com Sílio, que mirum uidetur apud imperatorem uirum quam imperatori nuptam esse.

104. Consentimento Matrimonial y Divorcio en Roma, p. 126, Ediciones Universidad de Salamanca, 1988. 
matrimonium dela com Cláudio só afasta as objeções feitas à de Volterra quanto a ter-se, em face do texto de Tácito, a união com Sílio como matrimonium iustum, não elidindo, porém, as objeções de que do texto do historiador romano corroborado pelo de Sêneca resulta que, apesar desse episódio, o casamento de Messalina com Cláudio persistiu, e de que, se a união dela com Sílio fosse um iniustum matrimonium que fizesse as vezes de repúdio em face de Cláudio, ficaria sem sentido a afirmação de Tácito de que Messalina, cansada da facilidade de seus adultérios, ad incognitas libidines profluebat, certo como é que a partir do iniustum matrimonium com Sílio não mais seria adulterina a relação entre eles, dissolvido que estaria o iustum matrimonium dela com Cláudio.

6. À concepção de que o casamento no Direito Romano clássico era um fato cuja persistência dependia, inclusive, do consentimento contínuo dos cônjuges se opõem objeções, tiradas de textos jurídicos e extrajurídicos do período clássico, que se me afiguram, até logicamente, intransponíveis. Tinha razão Tamassia $^{105}$ ao dizer que a construção da affectio maritalis era uma bela, mas absurda, utopia do mundo romanístico. O mesmo não ocorre com a concepção que de há muito temos por certa de que o casamento romano clássico, no tocante à vontade das partes, surgia de um ato inicial (ato jurídico que independia de forma) e demandava, para dissolver-se, de outro ato jurídico contrário àquele (o divórcio também aformal). Essa concepção, que apenas ficou mais evidenciada nos direitos pós-clássico e justinianeu, não força o sentido dos textos jurídicos ou extrajurídicos, e se coaduna com os em que os adeptos da tese do consentimento continuado buscam arrimo, inclusive no Digesto e no Código, tanto assim que Triboniano e seus colaboradores não tiveram necessidade de alterá-los ou suprimi-los.

105. Apud Rasi, ob. cit., p. 32, nota 2 iniciada na página anterior. 